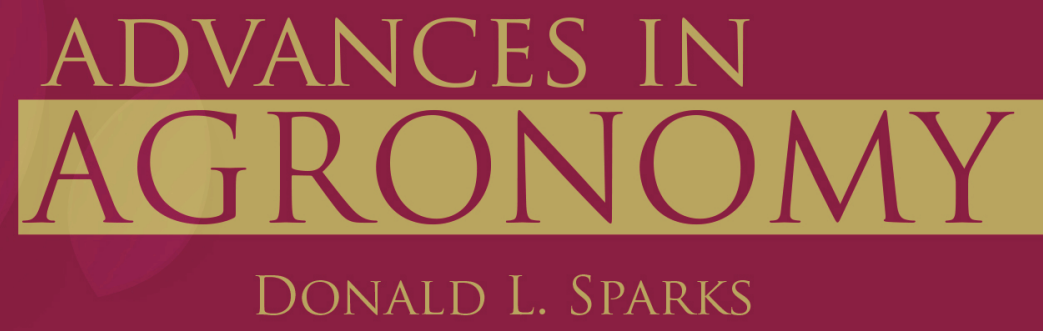

VOLUME 156

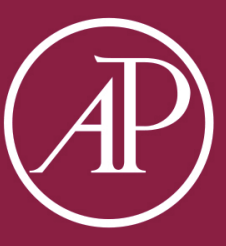


VOLUME ONE HUNDRED AND FIFTY SIX

\section{ADVANCES IN AGRONOMY}

Edited by

DONALD L. SPARKS

Delaware Environmental Institute,

Interdisciplinary Science and Engineering Laboratory,

University of Delaware, Newark, DE, United States
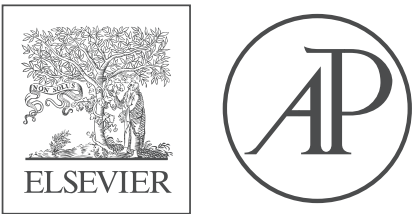

ACADEMIC PRESS

An imprint of Elsevier 


\title{
Ecological weed management in Sub-Saharan Africa: Prospects and implications on other agroecosystem services
}

\author{
Paolo Bàrberi* \\ Group of Agroecology, Institute of Life Sciences, Scuola Superiore Sant'Anna, Pisa, Italy, \\ *Corresponding author: e-mail address: paolo.barberi@santannapisa.it
}

\section{Contents}

1. Introduction 220

$\begin{array}{ll}1.1 \text { Sustainable vs ecological intensification } & 220\end{array}$

1.2 Ecological weed management: Definition, concept and scope 222

1.3 Ecological weed management vs integrated weed management 226

$\begin{array}{ll}\text { 2. Methodology } & 227\end{array}$

$\begin{array}{ll}2.1 & \text { Literature search strategy } \\ 2.2 & 227\end{array}$

2.2 Literature search outcome 230

2.3 Presentation of results 230

3. Ecological weed management in Sub-Saharan Africa 232

3.1 Ecological weed management of Striga spp. 233

4. Ecological weed management and agroecosystem services 247

4.1 Contribution of ecological weed management to ecological intensification

in Sub-Saharan Africa 247

4.2 Biodiversity: A tool to foster ecological weed management 248

4.3 Ecological weed management and small scale farming 249

$\begin{array}{ll}4.4 \text { Interactions with other agroecosystem services } & 250\end{array}$

$\begin{array}{ll}4.5 \text { Weeds as providers of agroecosystem services } & 251\end{array}$

$\begin{array}{ll}4.6 \text { Perspectives } & 252\end{array}$

Acknowledgments $\quad 254$

References $\quad 254$

$\begin{array}{ll}\text { Further reading } & 264\end{array}$

\section{Abstract}

In Sub-Saharan Africa weeds represent a major constraint to food production, and overreliance on herbicides, including toxic ones, is a raising issue. Nonetheless, effective nonchemical weed management practices are adopted by several Sub-Saharan farmers, and may foster ecological intensification and agroecological crop management in 
the region. Ecological Weed Management (EWM) is a combination of methods aimed to achieve long-term weed suppression through the use of ecological interactions between crop, weeds, soil and/or other taxa fostered by appropriate agroecosystem management, with the least possible use of direct weed control methods, chemical or non chemical. The opportunities offered by EWM in Sub-Saharan Africa are synthesized based on results of a comprehensive literature review. Ecological Weed Management of Striga spp., emblematic parasitic weeds in the area, is treated in details showing that effective methods exist and often work better when combined. These methods include, e.g., the development of cultivars resistant or tolerant of infection, improved crop rotations, cover crops, intercrops and mulches, other soil-based positive interactions, and biocontrol via use of pathogenic fungi. Strategies including functional biodiversity-based methods are expected to foster EWM and overall agroecological crop management in the region. EWM methods can support other agroecosystem services (e.g., soil fertility) and at the same time be improved by methods aiming at other services (e.g., push-pull strategies against maize cob borers). Transdisciplinary collaboration and scientists' engagement in participatory research and action with farmers and other stakeholders would be instrumental to facilitate broader adoption of EWM in Sub-Saharan Africa.

\section{Introduction}

\subsection{Sustainable vs ecological intensification}

The global quest for more sustainable cropping and farming systems should be framed in the context of two paradigms that have recently emerged: sustainable intensification and ecological intensification. Apparently, there is not much difference between them. Pretty et al. (2011) defined sustainable intensification, with special reference to Africa, as “... producing more output from the same area of land while reducing the negative environmental impacts and at the same time increasing contributions to natural capital and the flow of environmental services." Doré et al. (2011) defined ecological intensification as a system which produces more but differently, including production of bio-energy and other unconventional services.

In fact, sustainable intensification is often interpreted as a system which may rely on high-tech solutions like genetically modified organisms and robotics, whereas ecological intensification usually relies on improved solutions stemming from use of (mainly) local resources like agrobiodiversity at gene, species and habitat/ecosystem level (see Bàrberi, 2013 for a working definition of "agrobiodiversity") and improved knowledge on biological interactions occurring in an agroecosystem. In this context, environmentally-friendly management of agricultural weeds is of utmost importance, considering that 
weeds are worldwide considered the major biological cause of crop yield loss (Oerke, 2006). This is particularly relevant in socio-economically and environmentally fragile areas like Sub-Saharan Africa, where weeds can exacerbate food security problems and aggravate pollution and human health problems due to overuse and misuse of herbicides.

In this framework, ecological weed management (EWM) should mainly be seen as a set of practices which use locally available resources (mainly at the gene or species level of agrobiodiversity) to attain long-term weed suppression without the use of synthetic herbicides. Actually, limited and wise use of the latter may not necessarily reduce the efficacy of an EWM strategy, but whenever herbicides are part of a weed management strategy, they tend to be overused with possible negative consequences (Enserink et al., 2013). In fact, where herbicides are not used and where different practices are adequately combined (the "many little hammer" approach; Liebman and Gallandt, 1997) EWM can deploy its full potential. As such, this chapter focuses on weed management strategies and methods that do not imply the use of synthetic herbicides.

In Sub-Saharan Africa, there are serious concerns that increasing demography and the consequent need for increased food production might trigger increased and unsustainable use of herbicides. In 2010-11 the FAO carried out an expert survey involving a number of regional experts, with the goal to list the most difficult to control weeds as well as to highlight trends in herbicide use and in non chemical weed management methods (Gbèhounou, 2011, 2013). The survey included both agricultural and environmental (i.e., alien invasive species in natural areas) weeds. Although it is not always easy to make a clear-cut distinction between these two categories based on individual species, this chapter focuses on species which are mainly weeds in agricultural contexts, and on non-chemical methods for their management. The FAO survey was done in Ethiopia and Tanzania, as representative countries for East Africa conditions. Priority weed species listed by regional experts included weedy rice species and parasitic weeds of the genera Cuscuta, Striga, Orobanche and Phelipanche. Besides these, other weeds more common in West Africa were included in this study (see Table 2 for the full list of species). The FAO survey also highlighted an increasing use of herbicides (e.g., atrazine, bentazone, bromoxynil + MCPA, glyphosate, paraquat and $2,4-\mathrm{D})$, which is exacerbated by labor scarcity in a context where manual and hoe weeding are dominant practices. Fortunately, the survey revealed the existence of effective non-chemical and labor saving alternative ecological weed management practices adopted by farmers in a number of 
countries. As such, the study of non-chemical alternative weed management practices in Sub-Saharan Africa, including their effects on biodiversity and agroecosystem services, would provide baseline information for further implementation of EWM in the area, as an important component of ecological intensification and agroecological crop management (Gbèhounou and Bàrberi, 2016).

\subsection{Ecological weed management: Definition, concept and scope}

The term "ecological weed management" is relatively new and was first explicitly used in a book by Liebman et al. (2001), who intended it as "weed management procedures that rely on manipulations of ecological conditions and relationships." Another cornerstone reference on EWM was a review paper by Bastiaans et al. (2008), who basically identified EWM with cultural weed control, i.e., "... any adjustment or modification to the general management of the crop or cropping systems that contributes to the regulation of weed populations and reduces the negative impact of weeds on crop production" which "... involves the tactical and strategic level of decision making." Recently, Bagavathiannan and Davis (2018) have framed EWM within Barry Commoner's five laws of ecology "everything is connected with everything else," "everything must go somewhere," "everything is always changing," "there are no zero cost actions," "resources are finite," stressing once more the importance of a long-term system approach to weed management.

All the three above-mentioned references underline the importance of approaching weed management proactively rather than reactively, unlike what is common in herbicide-based systems. Bastiaans et al. (2008) ascribed EWM to three mechanisms which can be triggered by appropriate management practices: (i) reduction of weed seedling emergence, (ii) improved crop competitiveness and (iii) reduced weed seedbank size.

\subsubsection{Reduction of weed seedling emergence}

Reduction of weed seedling emergence can, e.g., be obtained by photocontrol, i.e., soil cultivation performed at night or under a lightproof carter to prevent that the light flash hitting weed seeds exposed to the soil surface would trigger germination. However, this method has shown erratic results (Ascard, 1994; Riemens et al., 2007), mainly due to the insensitivity of part of weeds seeds to light and/or to variable seed dormancy levels in actual weed populations. 
A second method to reduce weed seedling emergence is the use of mulching, using either natural or artificial mulches to cover the soil surface. Mulches exert their weed suppression effect by making the environment at the soil surface unsuitable for weed emergence (physical barrier, altered radiation) or through the release of allelopathic compounds (Davis, 2010; Marles et al., 2010).

\subsubsection{Improved crop competitiveness}

Improved crop competitiveness can be achieved by any management practice that shifts the temporal and/or spatial access to resources by crop and weeds in a direction favorable to the former and unfavorable to the latter. A first example is sowing or planting pattern. By increasing seeding rate, crops can be made more competitive against weeds because creation of a denser canopy would be accelerated (Anderson, 2009; O'Donovan et al., 2013). However, it should be pointed out that there is a cropdependent upper limit of canopy density beyond which competitive relationships between crop plants become too strong hence making increased seeding rate of no further practical use (Williams and Boydston, 2013). On the same line of thought, use of transplanting instead of sowing would make the crop straightforwardly more competitive than weeds by shifting the temporal access to resources between a larger plant (the crop) and smaller ones (the weeds) (Bàrberi, 2002; Tillett et al., 2008).

Competitive relationships between crops and weeds can also be altered by proper management of fertilization and irrigation. Specifically, localizing application of fertilizers and water along the crop rows facilitates capture of these resources by the nearest and stronger neighbor, which is usually the crop (Petersen, 2005). This can be seen as a way to shift the spatial access to resources between a closer-and usually larger-plant (the crop) and more distant and smaller ones (the weeds).

Crop-weed competitive relationships can also be altered by using competitive genotypes. This means selecting cultivars which possess competitive traits within the available gene pool of a crop. In general, traits like higher seed vigor, quicker emergence, higher height, higher attitude to tillering or branching, more developed root system are associated with a higher competitive ability (Andrew et al., 2015; Worthington et al., 2013). In addition, some crop cultivars can produce a relatively high amount of secondary metabolites with allelopathic potential, as it has been shown in the case of wheat, sorghum and rice (Bertholdsson, 2010; Sangeetha and Baskar, 2015). Using cultivars with increased competitive ability against weeds is 
an important tool in EWM because it would reduce the need to apply direct chemical or non-chemical weed control measures during the crop growing cycle.

One last method to increase crop competitive ability against weeds is recourse to polycultural systems. These are all those cropping and farming systems in which two or more plant species co-occur in the same area (e.g., field), providing more productive and non productive agroecosystem services compared to when each species is grown alone. In annual systems, polycultures take the form of either intercrops or living mulches. In intercropping all plant species (usually two) are cash crops whereas in living mulch systems a cash crop is grown side by side with a companion plant (the living mulch), whose biomass is not taken out of the system because it is recycled to improve the system itself and performance of the cash crop. Actually, in agricultural systems of Sub-Saharan Africa it is not easy to distinguish between an intercrop and a living mulch because the companion plant may at times be used as fodder or for other on-farm purposes.

Companion plant species in intercrops and living mulches can co-occur for a variable period of time, identifying different typologies of polycultures. For example, "relay cropping" is when a second species is interseeded within an already existing crop and concludes its life cycle after the crop has been harvested. Polycultures also include agroforestry systems, where annual and perennial plants (shrubs and/or trees) co-occur. Where animals are also included, the resulting mixed farming system is more properly called an "agrosylvopastoral system." Polycultural systems are quite common in many tropical and sub-tropical areas of the world and hold clear potential for improved weed suppression anywhere (Picasso et al., 2008).

\subsubsection{Reduced weed seedbank size}

The major part of weeds in agricultural land reproduce and survive as seeds, thus the soil weed seedbank represents the main source of future weed infestations. Depletion of the weed seedbank can be obtained by increasing seed losses and/or reducing seed inputs. Losses can occur through seed predation, seed decay, and increased germination (Gallandt, 2006).

Weed seed predation, especially after seeds have been shed on soil, may be an important determinant of seedbank losses (Davis et al., 2013; Westerman et al., 2011). Insects and small rodents are the main contributors to weed seed predation, thus manipulation of agricultural habitats as to attract them (e.g., no-till, delayed stubble cultivation, introduction of 
uncultivated strips within fields or as field margins) is expected to increase the number of weed seeds predated (Landis et al., 2005). Carabid beetles are among the most important consumers of weed seeds. It should be kept in mind that seed consumption by carabids is influenced by several factors, including weed species, seed physiological state, insects gender, activitydensity level, and seed burial depth (Kulkarni et al., 2015, 2016).

Weed seed decay is a mechanism so far poorly understood and consequently poorly exploited. It refers to the creation of soil conditions that are conducive to increased seed mortality through, e.g., fungal attack. Recently, some interesting results have been obtained by Gómez et al. (2014), who nevertheless pointed out that are differences in weed species susceptibility to decay, indicating the need to develop species- and cropping system-specific management solutions.

Increased weed seed germination results in an output to the seedbank. This can be achieved, e.g., by the application of the false- and stale-seedbed techniques, i.e., the anticipated soil seedbed preparation which allows stimulation of germination and emergence of weed seedlings that are subsequently destroyed before the actual crop seeding or crop emergence takes place (Cloutier et al., 2007). In the false seedbed technique seedling destruction usually occurs by harrowing or similar mechanical tools whereas in the case of the stale seedbed technique it occurs by chemical herbicides or by thermal methods (flame weeding or soil steaming), to avoid any further soil disturbance. Weed seed losses can also occur when seed germination is not followed by seedling emergence, usually because the seed is placed too deep down the soil and has not enough reserves in its endosperm to sustain seedling growth until it reaches the soil surface and becomes autotroph. This phenomenon is referred to as "fatal germination" (Fenner and Thompson, 2005).

Weed seedbank replenishment can also be avoided by preventing production and shedding of new seeds. This can be obtained as an outcome of increased competition or as an effect of a well planned crop rotation (Légère et al., 2011). However, it is also important to prevent seed shedding from late emerging weeds that, although usually unable to diminish crop yield in the same growing season, may create potential weed problems in subsequent crops or growing seasons through their seed inputs. Similarly, it is important to avoid weed seed shedding (e.g., by stubble cultivation or mowing) in the period between two crop growing cycles, an important issue that many farmers tend to disregard. 


\subsection{Ecological weed management vs integrated weed management}

In Bastiaans et al.'s (2008) definition, EWM does not include direct weed control methods, i.e., the in-crop application of chemical or non-chemical (mechanical, thermal, biological) methods that are deliberately used by farmers to eliminate weeds during crop growing cycle. Although the objective of EWM is to reduce recourse to direct weed control methods, it is undeniable that they are and will continue to be an important component of Integrated Weed Management (IWM). Since IWM is a widely recognized concept and EWM is an emerging one it is important to focus the similarities as well as the differences between them.

Shaw (1982) was probably the first to adopt the term Integrated Weed Management System, as an extension of the aims and concepts of Integrated Pest Management (IPM). He considered weed management (just like pest management) as one important component of overall agroecosystem management. In his view, the best approach to weed management is to design an agroecosystem that is less vulnerable to weed interference, by integrating all possible means of control (agronomic, genetic, biological, physical, and chemical) but with a main emphasis on prevention. As such, IWM and EWM look very similar, and arguably the main difference is that EWM (sensu Bastiaans et al., 2008) does not include direct weed control methods. However, it should be pointed out that, although there is an ongoing trend in bringing IWM closer to its intended approach, most papers published since 1982 considered IWM as just a combination of the use of synthetic herbicides with other non chemical direct weed control methods (mainly mechanical).

In the author's view, the distinction between preventive, cultural (sensu stricto) and direct methods (Bàrberi, 2002) is still preferable because it clearly distinguishes weed management methods based on (i) their main effect and (ii) the time when this effect manifest itself (before or during the crop growing cycle). In this framework, a preventive method is one applied before a crop is grown and whose main effect is to reduce weed emergence during the crop growing cycle. A cultural method is applied during the crop growing cycle and its main effect is to increase the competitive ability of the crop against weeds. Lastly, a direct method is any method applied during the crop growing cycle with the specific aim to eliminate emerged weeds.

Any IWM system should be composed of an appropriate integration of methods belonging to each of the three categories (preventive, cultural and direct), but with the main goal of reducing the use of direct methods, 
especially herbicides. As such, IWM becomes very similar to EWM, because emphasis is mainly placed on preventive and cultural methods. An updated definition of EWM could then be: "a combination of methods aimed to achieve long-term weed suppression through the use of ecological interactions between crop, weeds, soil and/or other taxa fostered by appropriate agroecosystem management, with the least possible use of direct weed control methods, either chemical or non chemical." There are two main advantages in this definition. The first is that it stresses the importance of reducing both chemical and non-chemical (e.g., mechanical or thermal) inputs, the latter being increasingly recognized as an environmental problem due to fuel consumption, soil degradation, and production of greenhouse gases also in systems with no synthetic herbicide use like organic farming (Armengot et al., 2015; Peigné et al., 2007). The second advantage is that it can be applied to any cropping, farming or management system anywhere. It is worthwhile noting that, according to this definition, an IWM system with a strong focus on ecological interactions is as a matter of fact an EWM system.

To better clarify the concept, the different typologies of methods highlighted in Sections 1.2.1-1.2.3 have been classified according to the above-mentioned definition of EWM (Table 1). Please note that if we consider "cover crop" - as often done-as one typology including green manure, dead mulches and living mulches, it should be considered a preventive method in the case of a green manure or dead mulch whereas it is a cultural method in the case of a living mulch. This classification has the advantage of clarifying the link between objectives, practical methods available to meet them, and their timing, and largely encompasses the methods and tools available for EWM in Sub-Saharan Africa.

\section{Methodology}

\subsection{Literature search strategy}

A comprehensive literature search was done in March 2015 and updated in August 2018 using the Elsevier Scopus ${ }^{\circledR}$ search engine (www.scopus.com). No time limit was initially set, but since the vast majority of records were related to ca. the latest 25-30 years, the search was subsequently adjusted to the 1990-2018 period. Although some potentially interesting "gray literature" on the subject exists, it was decided to focus only on scientific publications. 
Table 1 Classification of the different methods ascribed to ecological weed management according to their main effect, application timing and category, with relevant examples. ${ }^{a}$

\begin{tabular}{|c|c|c|c|c|}
\hline Method & Main effect & $\begin{array}{l}\text { Application } \\
\text { timing }\end{array}$ & Category & Examples \\
\hline Photocontrol & $\begin{array}{l}\text { Reduction in weed } \\
\text { emergence }\end{array}$ & $\begin{array}{l}\text { Before crop } \\
\text { cycle }\end{array}$ & Preventive & Night-time cultivation \\
\hline Mulching & $\begin{array}{l}\text { Reduction in weed } \\
\text { emergence/ } \\
\text { increase in crop } \\
\text { competitive ability }\end{array}$ & $\begin{array}{l}\text { Before/during } \\
\text { crop cycle }\end{array}$ & $\begin{array}{l}\text { Preventive/ } \\
\text { cultural }\end{array}$ & $\begin{array}{l}\text { Dead mulching/plastic } \\
\text { mulching }\end{array}$ \\
\hline $\begin{array}{l}\text { Sowing/ } \\
\text { planting } \\
\text { pattern }\end{array}$ & $\begin{array}{l}\text { Increase in crop } \\
\text { competitive ability }\end{array}$ & $\begin{array}{l}\text { During crop } \\
\text { cycle }\end{array}$ & Cultural & $\begin{array}{l}\text { Increased seeding rate, } \\
\text { reduced inter-row } \\
\text { distance }\end{array}$ \\
\hline Transplanting & $\begin{array}{l}\text { Increase in crop } \\
\text { competitive ability }\end{array}$ & $\begin{array}{l}\text { During crop } \\
\text { cycle }\end{array}$ & Cultural & $\begin{array}{l}\text { Use of transplants } \\
\text { instead of seeds }\end{array}$ \\
\hline $\begin{array}{l}\text { Fertilization } \\
\text { (localized) }\end{array}$ & $\begin{array}{l}\text { Increase in crop } \\
\text { competitive ability }\end{array}$ & $\begin{array}{l}\text { During crop } \\
\text { cycle }\end{array}$ & Cultural & $\begin{array}{l}\text { Banded fertilization, } \\
\text { seed dressing }\end{array}$ \\
\hline $\begin{array}{l}\text { Irrigation } \\
\text { (localized) }\end{array}$ & $\begin{array}{l}\text { Increase in crop } \\
\text { competitive ability }\end{array}$ & $\begin{array}{l}\text { During crop } \\
\text { cycle }\end{array}$ & Cultural & Drip row irrigation \\
\hline $\begin{array}{l}\text { Competitive/ } \\
\text { resistant } \\
\text { genotypes }\end{array}$ & $\begin{array}{l}\text { Increase in crop } \\
\text { competitive ability }\end{array}$ & $\begin{array}{l}\text { During crop } \\
\text { cycle }\end{array}$ & Cultural & $\begin{array}{l}\text { Use of cultivars with } \\
\text { higher tillering ratio } \\
\text { and/or allelopathic } \\
\text { potential, or resistant } \\
\text { to parasitic weeds } \\
\text { (e.g., Striga spp.) }\end{array}$ \\
\hline Polycultures & $\begin{array}{l}\text { Increase in crop } \\
\text { competitive ability }\end{array}$ & $\begin{array}{l}\text { During crop } \\
\text { cycle }\end{array}$ & Cultural & $\begin{array}{l}\text { Intercropping, living } \\
\text { mulches, agroforestry }\end{array}$ \\
\hline $\begin{array}{l}\text { Seed } \\
\text { predation }\end{array}$ & $\begin{array}{l}\text { Reduction in weed } \\
\text { emergence }\end{array}$ & $\begin{array}{l}\text { Before crop } \\
\text { cycle }\end{array}$ & Preventive & $\begin{array}{l}\text { Untilled field margin } \\
\text { strips to attract seed } \\
\text { predators }\end{array}$ \\
\hline Seed decay & $\begin{array}{l}\text { Reduction in weed } \\
\text { emergence }\end{array}$ & $\begin{array}{l}\text { Before crop } \\
\text { cycle }\end{array}$ & Preventive & $\begin{array}{l}\text { Incorporation of } \\
\text { residues, green manures } \\
\text { or composts }\end{array}$ \\
\hline $\begin{array}{l}\text { Increased } \\
\text { germination }\end{array}$ & $\begin{array}{l}\text { Reduction in weed } \\
\text { emergence }\end{array}$ & $\begin{array}{l}\text { Before crop } \\
\text { cycle }\end{array}$ & Preventive & $\begin{array}{l}\text { False/stale seedbed } \\
\text { technique, use of } \\
\text { germination stimulants }\end{array}$ \\
\hline $\begin{array}{l}\text { Preventing } \\
\text { seed shedding }\end{array}$ & $\begin{array}{l}\text { Reduction in weed } \\
\text { emergence }\end{array}$ & $\begin{array}{l}\text { Before crop } \\
\text { cycle }\end{array}$ & Preventive & $\begin{array}{l}\text { Stubble cultivation or } \\
\text { spraying }\end{array}$ \\
\hline $\begin{array}{l}\text { Direct weed } \\
\text { control } \\
\text { methods }\end{array}$ & $\begin{array}{l}\text { Elimination of } \\
\text { emerged weeds }\end{array}$ & $\begin{array}{l}\text { During crop } \\
\text { cycle }\end{array}$ & Direct & $\begin{array}{l}\text { Chemical, physical } \\
\text { (e.g., mechanical, } \\
\text { thermal), biological }\end{array}$ \\
\hline
\end{tabular}

${ }^{a}$ Elaborated upon Bastiaans et al. (2008) and Bàrberi (2002). 
Given the complexity of the subject, several search runs were done using various search terms and combinations thereof. "Ecological weed management" was searched as a stand alone term, with the intention of gathering also relevant records not necessarily related to Sub-Saharan Africa. Instead, the other general terms that were expected to yield many results relevant for this study, i.e., "integrated weed management" and "cover crop*" were matched with the regional term "Africa." The 23 weed species or genera highlighted as most difficult to control in the above-mentioned FAO report were searched individually without any geographical restriction, adding the search term "control" or "weed*" to narrow the search in the case of species or genera with known alternative use (e.g., Cynodon dactylon is not only a weed but also a valued turf grass species as well as the Ipomoea genus include both noxious weeds and sweet potato). Also, three cover crops (Arachis pintoi, Canavalia ensiformis and Desmodium uncinatum) and one crop (banana) were searched individually, adding the term "weed*".

In details, the search terms used were:

- "ecological weed management";

- "integrated weed management" AND "Africa";

- "cover crop*" AND "Africa";

- "banana" AND "weed";

- "Arachis pintoi" OR "Canavalia ensiformis" OR "Desmodium uncinatum" AND "weed*";

- "Amaranthus spinosus";

- "Argemone mexicana";

- "Chromolaena odorata";

- "Commelina benghalensis";

- "Convolvulus arvensis" AND "control";

- "Cuscuta" AND "control"

- "Cynodon dactylon" AND "control";

- "Cyperus" AND "control";

- "Digitaria" AND "control";

- "Ipomoea" AND "weed*";

- "Leptochloa";

- "Mikania micrantha";

- "Orobanche cernua";

- "Orobanche crenata";

- "Phelipanche ramosa";

- "Oryza longistaminata";

- "Oryza punctata"; 
- "Parthenium hysterophorus" AND "weed*";

- "Prosopis juliflora" AND "weed*";

- "Rottboellia cochinchinensis";

- "Snowdenia polystachya";

- "Striga asiatica";

- "Striga hermonthica."

Asterisks $(*)$ indicate a truncated search term. For example, "weed*" would yield records containing the term "weed" and all its derivatives, e.g., "weeds," "weeding" or "weedy" in the article title and/or abstract.

\subsection{Literature search outcome}

Overall, the combination of all search runs yielded 7046 records, reduced to 6232 after purging duplicates. These records were thoroughly screened to identify those related to EWM, and classified in sub-groups using the EndNote $^{\mathrm{TM}}$ (version X3) literature archiving software. In some cases (e.g., Convolvulus arvensis and Cynodon dactylon) numerous records were retrieved but only few of them were relevant to EWM applications in Africa hence the rest was discarded. In contrast, in the case of Striga spp. the majority of records were relevant to this study, because of the high regional importance of this genus and the proven effectiveness of some EWM solutions for its control. Only one record was retrieved for Snowdenia polystachya.

Overall, the database was constructed as to favor representation of the diversity of approaches, techniques and uses over complete retrieval of what was published on the subject. In the end, the various selection criteria used to refine the database yielded a total of 641 articles (Table 2 ). The vast majority of papers retrieved were published after 2000.

\subsection{Presentation of results}

Results are presented by first introducing the general subject of EWM in Sub-Saharan Africa. Subsequently, EWM of Striga spp. will be treated in details: these are key agricultural weeds which yielded by far the highest number of published records (Table 2), and against which a vast array of EWM tactics is being deployed.

The direct or indirect contribution of EWM practices to the provision of agroecosystem services besides weed suppression has been indirectly drawn from the literature using the above-mentioned search terms and is presented in Section 4. Using search queries like "ecological weed management" AND "ecological" OR "(agro)ecosystem service*" would not yield 
Table 2 Subjects included in the EndNote ${ }^{\mathrm{TM}}$ literature database on ecological weed management in Sub-Saharan Africa, respective number of records, ${ }^{a}$ and prevailing weed type in the study region for the selected species

\begin{tabular}{|c|c|c|}
\hline Subject & Number of records & $\begin{array}{l}\text { Prevailing weed type } \\
\text { in the region }\end{array}$ \\
\hline Ecological weed management & 33 & - \\
\hline Integrated weed management & 10 & - \\
\hline Cover crops & 56 & - \\
\hline Herbicide resistant crops & 1 & - \\
\hline Sowing time & 1 & - \\
\hline Tillage & 8 & - \\
\hline Amaranthus spinosus & 23 & Agricultural \\
\hline Argemone mexicana & 23 & Agricultural \\
\hline Chromolaena odorata & 54 & Agricultural \\
\hline Commelina benghalensis & 25 & Agricultural \\
\hline Convolvulus arvensis & 12 & Agricultural \\
\hline Cuscuta spp. & 10 & Agricultural \\
\hline Cynodon dactylon & 4 & Agricultural \\
\hline Cyperus spp. & 25 & Agricultural \\
\hline Digitaria spp. & 6 & Agricultural \\
\hline Echinochloa spp. & 3 & Agricultural \\
\hline Imperata cylindrica & 5 & Agricultural \\
\hline Ipomoea spp. & 11 & Environmental \\
\hline Leptochloa chinensis & 4 & Agricultural \\
\hline Mikania micrantha & 24 & Environmental \\
\hline Orobanche and Phelipanche spp. & 38 & Agricultural \\
\hline Oryza longistaminata & 5 & Agricultural \\
\hline Parthenium hysterophorus & 51 & Environmental \\
\hline Prosopis juliflora & 10 & Environmental \\
\hline Rottboellia cochinchinensis & 8 & Agricultural \\
\hline Snowdenia polystachya & 1 & Agricultural \\
\hline Striga spp. & 192 & Agricultural \\
\hline Total $^{\mathrm{b}}$ & 641 & - \\
\hline
\end{tabular}

${ }^{\mathrm{a}}$ Literature search performed on the Scopus ${ }^{\mathrm{TM}}$ database (17 August 2018). For details on the search strategy see Section 2.1. Records related to Arachis pintoi, Canavalia ensiformis and Desmodium uncinatum spanned across several subjects and therefore are not presented separately. No records relevant to the scope of this study were retrieved for Oryza punctata.

${ }^{\mathrm{b}}$ The sum of records by subject is 643 because two papers dealt with two of the selected weed species at once. 
appreciable results because both terms are quite novel, especially when used in conjunction. A reverse perspective, i.e., the contribution of selected weeds to the provision of agroecosystem services important for Sub-Saharan agriculture is also included.

\section{Ecological weed management in Sub-Saharan Africa}

Most of the examples of EWM applications refer to studies carried out in West Africa (e.g., Benin, Cameroon, Ghana, Ivory Coast, Nigeria), with the noticeable exceptions of Kenya and-to a lower extent-Ethiopia. All the records that explicitly figured EWM as term in title and/or abstract date from 2001 onward, witnessing the recent acquisition of the term in the scientific literature. It is worth noting that none of the remaining 608 papers (94.8\% of the total) used the term Ecological Weed Management despite the fact that they actually deal with EWM approaches and solutions.

Just like EWM, a large number of papers actually dealt with IWM without mentioning it explicitly. Due to ample overlapping in concepts and practices between papers explicitly referring to IWM and EWM no further distinction between them has been done.

Interestingly, one of the first proofs of EWM success in Africa-which has become a classic case-was likely driven by serendipity. Khan et al. (2000) developed an intercropping and trap crop system using a "push-pull" strategy for the control of stem borers in small scale maize farming systems. Their strategy involved trapping stemborers on highly susceptible trap plants (pull) and driving them away from the crop using repellent intercrops (push). Napier grass (Pennisetum purpureum) and Sudan grass (Sorghum vulgare var. sudanense) were used as trap plants, whereas molasses grass (Melinis minutiflora) and two legume species (Desmodium uncinatum and D. intortum) were used as repellents of ovipositing stemborers. Although the system was meant to control stemborers, it was observed that the introduction of silver leaf desmodium (D. uncinatum) drastically reduced maize damage by parasitic Striga species.

Striga spp. are here treated as model weeds for the implementation of EWM in Sub-Saharan Africa. Indeed, the severe problems caused by striga infestations have triggered a wealth of research on the development of alternative control methods, spanning from cropping system diversification (crop rotation, cover crops, intercrops) to soil amendments and mulching, allelopathy, tolerant or resistant cultivars, biological control and others. 


\subsection{Ecological weed management of Striga spp.}

Striga (witchweeds), of the family Orobanchaceae, is a genus of parasitic plants occurring in part of Africa, Asia, and Australia and-to a lower extent-in the Americas. Some species are serious weeds of cereal crops (e.g., maize, sorghum, millet, rice), especially in African savannah-type agriculture, but can parasitize other crops, e.g., legumes and sugarcane. Striga spp. has been estimated to affect ca. 40 million ha of cropland in Sub-Saharan Africa, where it can be devastating in smallholders subsistence farming (Anonymous, 2006).

The three species causing most damage are Striga asiatica, S. gesnerioides, and S. hermonthica. The only other Striga species considered of some agricultural importance is $S$. aspera, a rice weed found in both free-draining uplands and hydromorphic soils (Rodenburg et al., 2010).

S. asiatica (Asian witchweed) has a very wide geographical range, from Africa to South and East Asia down to Australia, and is also present in the United States since the 1950s. S. gesnerioides (cowpea witchweed) is a parasite of cowpea, while S. hermonthica (purple witchweed) parasitizes grasses, especially sorghum and pearl millet, across all Sub-Saharan Africa. Another 25 Striga species exist but at the moment are not considered of agricultural importance. Alectra vogelii (yellow witchweed), a parasitic weed of legume crops similar to striga, has been found on groundnut in Ethiopia (Hussien et al., 2006) and in other semi-arid Sub-Saharan African countries, but is considered a widespread species only in Botswana, Malawi, Tanzania, and Zimbabwe (http://www.cabi.org/isc/datasheet/4234).

Witchweeds are obligate root hemiparasites and require a living plant host for triggering germination and initial development. Host plant symptoms include stunting, wilting, and chlorosis, and can be confused with those of drought, nutrient deficiency or vascular disease. Host root parasitization may progress for up to 7 weeks after root colonization. When the weed emerges, much of the damage has already been done; the parasitic plant then rapidly flowers and sets seeds.

Much of the problem of Striga spp. is due to their high fecundity (each plant can produce up to 500,000 seeds) and seed longevity in soil ( $>10$ years). The tiny witchweed seeds can be easily spread by wind, water, soil movement or animal vectors, including human transportation through machinery, tools, and clothes.

Seeds germinate in the presence of host root stimulating exudates (strigolactones) and develop haustoria which penetrate host root cells 
(Charnikhova et al., 2017; Pageau et al., 2003). Optimum witchweed seed germination occurs with soil temperatures between 30 and $35^{\circ} \mathrm{C}$ $\left(\mathrm{T}_{\min }=20^{\circ} \mathrm{C}\right)$ and adequate moisture. Striga seeds can survive very low soil temperatures, down to $-15^{\circ} \mathrm{C}$. These weeds thrive in light-textured poor soils with low nitrogen level but can adapt to different soil textures. Climate change may indirectly worsen striga problems due to negative effects on soil fertility, yet the impact of $S$. hermonthica on upland rice (a $C_{3}$ crop) may be lower because witchweed infection can delay down-regulation of photosynthesis in rice grown at elevated $\mathrm{CO}_{2}$ (Watling and Press, 2000).

Striga spp. populations from Kenya have been found to have a relatively low genetic diversity (Gethi et al., 2005) but Welsh and Mohamed (2011) and Estep et al. (2011) observed high genetic diversity in Ethiopian and Malian populations of $S$. hermonthica, respectively. This was mainly attributed to the geographical barrier posed by the Rift Valley in the first case and to inadvertent human transportation of seeds across regions in the second. East African S. hermonthica populations, especially those from Sudan, had significantly greater average infestation success across 16 sorghum genotypes than West African populations (Bozkurt et al., 2015). High genetic variation among individuals of each population points out the high potential this weed has to adapt to different hosts and environments. S. hermonthica populations parasitising rice in Kenya appeared to be genetically distinct from those parasitising maize and sorghum. The presence of distinct populations in East and West Africa suggests the importance of developing and testing striga control technologies in multiple locations (Unachukwu et al., 2017).

\subsubsection{Striga-tolerant and resistant genotypes}

Besides classical agronomic prevention measures based on common sense, e.g., sowing uncontaminated crop seeds in striga-clean soil and accurate cleaning of agricultural machinery, tools and clothes, selection of crop genotypes tolerant of or resistant to witchweeds is one major preventive route.

Considerable research on this subject has been carried out since the early 2000s. Resistance to S. hermonthica through screening of 274 wild Pennisetum glaucum subsp. monodii and stenostachym accessions was searched in Mali (Wilson et al., 2000). Visual maize damage score at 8 weeks after planting was significantly correlated $(r=0.82-0.88)$ to shoot reduction at late crop growth stages hence, under high and uniform infestation, maize mature plant resistance can be detected at that stage, i.e., the onset of flowering (Adetimirin et al., 2000). 
Complete resistance to striga infection is hard to find in cereals, but screening of crop wild relatives may provide useful genes for the development of resistant crops. For example, Sorghum arundinaceum, a wild relative of cultivated sorghum, demonstrated tolerance to infection by $S$. asiatica although not to S. hermonthica (Gurney et al., 2002). Other wild sorghum species have been screened for this purpose, with some success (Mbuvi et al., 2017). Screening of sorghum landraces can also provide valuable tolerant or resistant germplasm to be utilized in future breeding programmes (Abate et al., 2014, 2017a). Lower root length, root length density, root to shoot ratio and root dry weight are root traits characterizing tolerant or resistant sorghum genotypes (Abate et al., 2017b). Tripsacum dactyloides, a maize wild relative, and a maize- $T$. dactyloides hybrid showed partial resistance to S. hermonthica (Gurney et al., 2003), possibly due to production of a signal inhibiting haustorial development. Another wild relative of maize thought to provide useful striga-resistant genes is Zea diploperennis (Yallou et al., 2009).

Cowpea lines resistant to $S$. gesnerioides have been developed, showing an average grain yield increase of $156 \%$ over standard, susceptible lines (Carsky et al., 2003). Several cowpea resistance genes effective against specific races of $S$. gesnerioides have been identified, giving the potential to develop cowpea varieties with multiple resistance genes (Boukar et al., 2004).

Both resistance and tolerance are important in determining sorghum yield potential under striga infestation (Rodenburg et al., 2005). Tolerance and resistance seems relatively more important under low and high infestation levels, respectively. However, only at very low infestation levels the use of high resistant genotypes seems able to reduce striga seedbank (Rodenburg et al., 2006). Photosynthesis-related highly heritable traits like $\mathrm{CO}_{2}$ assimilation rate and photochemical quenching are reliable estimators of striga tolerance in sorghum genotypes (Rodenburg et al., 2008). Combination of (at least partly) striga-tolerant varieties and $\mathrm{N}$ fertilizer application (50-100 $\mathrm{kgha}^{-1}$ ) has been suggested as optimum IWM/EWM solution in sorghum (Showemimo et al., 2002).

Substantial work on striga-resistant maize has been done in Ivory Coast, where promising early maturing inbred lines have been found (BaduApraku and Lum, 2007; Badu-Apraku et al., 2006; Menkir, 2006). Sodium azide $\left(\mathrm{NaN}_{3}\right)$-induced mutagenesis can transform striga-susceptible maize cultivars into resistant ones with stable performances, as shown in western Kenya (Kiruki et al., 2006). 
One important mechanism conferring resistance to striga is lower production of strigolactones, as found in several maize landraces (Karaya et al., 2012), that can be used to develop new striga resistant inbred lines. Higher levels of striga germination were observed in some inbred lines known to be resistant, suggesting the existence of a parasitization avoidance mechanism in the host root system that is independent of the amount of strigol produced. On top of this, it was recently found that maize can possess both pre-attachment and post-attachment (inability to penetrate host endodermis) resistance mechanisms (Mutinda et al., 2018). Interestingly, some $S$. hermonthica-resistant maize hybrids have shown consistent levels of resistance across different locations and seasons in Nigeria and Kenya (Menkir et al., 2012).

Striga-tolerant or resistant genotypes have also been found in rice, where putative quantitative trait loci have been identified (Gurney et al., 2006). Low germination induction is an important tolerance/resistance mechanism also in rice. Besides this, a negative correlation between rice tillering capacity and strigolactone production has been found (Jamil et al., 2012a). Cissoko et al. (2011) screened the interspecific upland NEw RICe for Africa (NERICA) cultivars (developed from crosses between high-yielding Oryza sativa and weed competitive and disease resistant Oryza glaberrima and quite popular among subsistence farmers) for their post-attachment resistance against ecotypes of $S$. hermonthica and $S$. asiatica. Some NERICA cultivars showed good broad-spectrum resistance against several striga ecotypes, while others showed intermediate or no resistance. In western Kenya, NERICA 1 and NERICA 10 have been classified as resistant to S. hermonthica, whereas NERICA 4 is highly susceptible (Atera et al., 2012). In the most resistant NERICA cultivars, damage from striga interference is limited but even a small striga density can cause some reduction in rice aboveground biomass. Nevertheless, use of competitive NERICA cultivars is an excellent EWM tactic in striga-free soils (Rodenburg and Johnson, 2009; Rodenburg et al., 2009). Additional rice genotypes with either ecotype-specific or broad-spectrum resistance to striga have recently been identified (Rodenburg et al., 2017).

In the latest years, research has directed efforts toward the selection of cereal cultivars combining tolerance to multiple stresses, e.g., tolerance to drought and S. hermonthica in maize (Kamara et al., 2012; Mengesha et al., 2017), and tolerance to striga and downy mildew (Sclerospora graminicola) in pearl millet (Pennisetum glaucum) (Kountche et al., 2013). In this latter case, infestation in Nigerien and Malian fields was reduced by $51 \%$ (striga) and 46-62\% (downy mildew), determining pearl millet panicle yield gains of 
$31-49 \%$. The germplasm screened showed significant genetic variation and high genotype $\times$ environment interaction, suggesting local target selection of parentals. An interesting side effect of some striga-tolerant varieties of maize is that they are also resistant to maize streak virus and other diseases endemic in West and Central Africa (Kim et al., 2002).

A recent technological advancement proposed for the genetic improvement of maize resistance against striga is the use of RNA interference (RNAi), i.e., the transformation of the host crop by the inclusion of RNAi sequences targeted at critical striga genes (Kirigia et al., 2014). At present, application is limited by lack of efficient high throughput screening protocols for silencing candidate genes, and by sub-optimal delivery of silenced RNAs into the parasite. Compared to stable transformation, viral induced gene silencing (VIGS) seems a more rapid and powerful tool for effective screening of candidate genes to target through RNAi. Tobacco rattle virus (TRV1 and TRV2) vectors had 60\% efficiency in silencing the phytoene desaturase (PDS) gene in S. hermonthica, showing that the system is reliable and can be used for candidate gene validation, with the ultimate goal of developing striga-resistant transgenic maize.

\subsubsection{Arbuscular mycorrhizal fungi}

Role of arbuscular mycorrhizal fungi (AMF) in sorghum resistance to $S$. hermonthica has been suggested, pointing out the need to consider side effects on AMF colonization when breeding for striga resistance (Lendzemo and Kuyper, 2001). This hypothesis was later explored by Gworgwor and Weber (2003), who found that Glomus (Funneliformis) mosseae reduced striga density by $62 \%$, increased sorghum growth and aboveground biomass by $30 \%$, and did not affect root biomass unlike other AMF species, which increased the root: shoot ratio.

Field inoculation of AMF (Glomus clarum and Gigaspora margarita) in Cameroon significantly reduced S. hermonthica shoots (by 30\% in maize and $>50 \%$ in sorghum) and biomass (40\% in maize, and $46-63 \%$ in sorghum) after AMF inoculation, but beneficial effects on grain yield were observed only in sorghum (Lendzemo et al., 2005). It has been hypothesized that the negative effect of AMF colonization on striga seed germination, haustoria attachment and shoot emergence could be mediated through the production of signaling molecules (strigolactones) for both AMF and the parasitic species (Lendzemo et al., 2007). However, not all plants that are AMF hosts stimulate striga seed germination through their root exudates, whereas AMF non host plants never showed such 
effect (Lendzemo et al., 2009). Lack of germination stimulation in some AMF host plants may be due to differences in type and/or concentration of strigolactones in root exudates linked to the two processes (striga seed stimulation and establishment of AMF symbiosis).

\subsubsection{Stimulation or inhibition of seed germination}

Stimulation of suicidal witchweed seed germination by exudates of non host "trap" crops is another effective preventive method in a striga EWM strategy. This effect can, e.g., be triggered by limonoids, a class of compounds isolated from the root bark of the African shrub Harrisonia abyssinica (Rutaceae), which showed up to $98 \%$ stimulatory activity of conditioned $S$. hermonthica seeds when applied at $10^{-3}-10^{-5} \mathrm{M}$ concentrations under laboratory conditions (Rugutt et al., 2001).

Cotton (Gossypium hirsutum and G. barbadense) is a known trap crop for Striga spp., being able to stimulate suicidal germination. Cotton genotypes showed high variability for this trait (13-50\% striga seed germination), which is qualitatively inherited with monogenic control: this would make it possible to select and breed cotton cultivars able to produce high amounts of germination stimulants while maintaining or improving other positive agronomic traits (Botanga et al., 2003).

The effectiveness of root exudates from varieties of cowpea, groundnut and soybean on $S$. hermonthica seed germination depends on striga population hence geographical origin of the weed, host crop, period of the year, and seed age should be taken into account to better target potential trap crops (Gbèhounou and Adango, 2003).

Considerable variation among soybean varieties in their ability to induce germination of S. hermonthica (from $8 \%$ to $66 \%$, compared to $70 \%$ of the synthetic stimulant strigol) was found in a maize-soybean intercropping trial (Odhiambo et al., 2011). Some varieties showed high stimulation but low haustoria attachment. Intercropping reduced striga shoot emergence and increased maize yield. Similarly, significant differences between 9 cotton, 15 cowpea, and 6 groundnut genotypes in their ability to induce suicidal germination of $S$. hermonthica seeds was detected in a bioassay (Traoré et al., 2011).

Striga management can be improved also by aiming at the opposite effect, i.e., seed germination inhibition. Sorghum seed treatment with $\mathrm{NaCl}$ at $1.5 \mathrm{M}$ significantly reduced striga emergence in both resistant and susceptible varieties, and had a positive effect on crop growth and grain yield, although the mechanism is unclear (Gworgwor et al., 2002). 
Neem (Azadirachta indica) seed powder and parkia (Parkia biglobosa) fruit powder or fruit peel powder effectively reduced $S$. hermonthica germination and growth in sorghum (17\%,29\% and 39\% striga emergence, respectively), with positive effects on crop grain yield (Marley et al., 2004b).

Cultivation of high-value medicinal herbs with $S$. hermonthica germination induction properties has been proposed as a viable agronomic strategy in striga-infested soils (Ma et al., 2004). Twenty out of 383 water and methanolic extracts of traditional Chinese medicinal herbs were found to induce $S$. hermonthica germination, some at rates $>50 \%$. On the opposite side, water or undiluited extracts from 27 herbs inhibited S. hermonthica germination, with Curcuma longa undiluted extract showing a complete inhibitory effect. A stimulatory effect was also observed from fresh plant tissues, tissue powder and root extracts of Houttuynia cordata (Saururaceae) (Ma et al., 2005). Aqueous extracts or lyophilisats from four burkinabé plant species reduced striga seed germination by at least $96 \%$, whereas $1 \%$ aqueous extracts of Ceiba pentandra and Eucalyptus camaldulensis stimulated striga seed germination by $39 \%$ compared to the control (Yonli et al., 2010).

Recently, detection of compounds inducing suicidal germination in witchweeds has been improved by using a high-throughput Arabidopsisbased strigolactone perception system. Through Arabidopsis-based assays, three compounds with in planta strigolactone activity stimulating suicidal germination in S. hermonthica were found (Toh et al., 2014).

\subsubsection{Cropping system diversification (crop rotation, cover crops, intercropping, agroforestry)}

In northern Nigeria, soybean was shown to be an effective preceding crop in reducing $S$. hermonthica emergence in subsequent maize, increasing yield by an average $90 \%$ as compared to sorghum (Carsky et al., 2000). Application of $\mathrm{P}$ to soybean grown at higher soybean densities enhanced weed reduction and the positive effect on maize.

Oswald and Ransom (2001) evaluated the effect of eight crop rotations including striga non-host crops on striga seedbank reduction and low-input rainfed maize yield in western Kenya. Several crops (e.g., peanut, soybean, sunflower and pigeon pea) showed greater economic potential than maize. The best crop rotation under low soil fertility had a five-fold productivity than maize mono-cropping. All crop rotations reduced striga seedbank, and lower striga emergence occurred where maize was planted after a twoseason rotation including pigeon pea. Crop rotation diversification should 
be systematically included in smallholder farming in eastern Africa because it is a cheap and effective way to control striga and boost maize and overall farm productivity.

Introduction of legume food crops like soybean or bambara groundnut (Vigna subterranea) as an alternative to bush fallow system in the Sudan savannah zone of Ghana dramatically decreased S. hermonthica infestation, confirming that increasing soil fertility is an ecological and easy way to reduce problems caused by witchweeds (Abunyewa and Padi, 2003). Similar results were obtained in north-eastern Ghana when matching the introduction of soybean as preceding crop with the use of striga-tolerant maize varieties (Abdulai et al., 2006).

Growing sesame in rotation with pearl millet has also been shown to strongly reduce striga density and reproduction potential compared to sole millet. In the Sahel, this technique has to be matched with soil fertility enhancement and water conservation to obtain stable effects (Hess and Dodo, 2004). Results of a simulation modeling study (Van Mourik et al., 2008) showed that intercropping millet with sesame or cowpea (plus weeding) was able to reduce $S$. hermonthica seedbank in the long term. However, rotation of millet with trap crops was not effective because seedbank replenishment during the years of millet monoculture was not offset by seedbank depletion in the years of trap crop cultivation.

In the northern Guinea savannah of Nigeria, intercropping tolerant maize varieties with either soybean or groundnut proved to be a successful strategy to reduce striga interference and increase crop yield (Kuchinda et al., 2003). Similar results, although with some variation among locations, were obtained in the same area with cowpea or soybean as a trap crop and by maize-cowpea intercropping (Ellis-Jones et al., 2004; Kureh et al., 2006). Sorghum-cowpea intercropping in alternate ridge pattern was also found to be successful, although care should be taken in choosing the most suitable cowpea cultivar (Udom et al., 2007). Farmers in the area seemed to prefer a legume-cereal rotation over other 14 potential witchweed control means (Emeghebe et al., 2004). Interestingly, resource-poor and -intermediate farmers were more likely to adopt IWM/EWM solutions for striga control than resource-rich farmers. Introduction of soybean cultivation was particularly liked by women because of the opportunity to sell new food products based on this legume (Douthwaite et al., 2007). These results were confirmed by a participatory project carried out in the same region (Kamara et al., 2008), that also highlighted the importance of farmer-to-farmer extension to turn potential into real innovation. Increased labor requirements, 
sometimes associated to the introduction of new varieties and management practices, was not perceived as a major obstacle.

As mentioned before, two commonly used plants in intercropping systems are the legumes silverleaf and greenleaf desmodium (Desmodium uncinatum and $D$. intortum, respectively), which not only suppress $S$. hermonthica but also repel maize stem borers through allelopathic effects (Khan et al., 2000, 2006b). Similar effects have been found on sorghum (Khan et al., 2006a) and finger millet (Eleusine coracana) (Midega et al., 2010). The allelopathic effect of D. uncinatum involves production of a germination stimulant as well as of an inhibitor of haustorial development (Khan et al., 2002). Hooper et al. $(2009,2010)$ identified the responsible allelochemical as isoschaftoside, a di-C-glycosylflavone isolated from desmodium root extracts and exudates. It is worth noting that the biosynthetic pathway of this compound class is often present in edible legumes and in cereals, thus there is potential to introduce this striga-protection mechanism in crops. Intercropping sorghum with cowpea, greengram (Vigna radiata) or crotalaria (Crotalaria ochroleuca) provided stable striga suppression, but only a sorghum-greenleaf desmodium intercrop was able to increase sorghum yield (Khan et al., 2007). On the agronomic side, maize-desmodium intercrop also provides valuable forage for cattle, an important asset for subsistence cereal production systems of Sub-Saharan Africa. Agronomic benefits can be further improved by selecting an appropriate desmodium biomass cutting regime (Kifuko-Koech et al., 2012). Maize residues applied as mulch in combination with $\mathrm{N}$ fertilization can reduce striga emergence in a subsequent maize crop, but far less than what can be obtained by a well managed maizedesmodium intercrop (Midega et al., 2013). Integration of edible beans (Phaseolus vulgaris) in maize-desmodium intercrops retained S. hermonthica and stem borers control efficacy while increasing attractiveness to Kenyan farmers, despite the increase in labor (Khan et al., 2009). Where labor is not a limiting factor, maize and beans should be planted in separate holes to avoid competition for water and nutrients. In a perspective of climate change, use of Desmodium incanum and D. ramosissimum may become preferable due to better retention of leaves and their functionality under drought stress conditions compared to other desmodium species, coupled with higher above ground biomass, effective striga suppression and increased grain yield (Midega et al., 2017).

In moderately striga-infested fields, fallows planted with Desmodium distortum, Sesbania sesban, Sesbania cinerascens, Crotalaria grahamiana and Tephrosia vogelii reduced striga infestation by $40-72 \%$ and increased maize grain yield 
by $224-316 \%$ compared with continuous maize, an effect likely due to a combination of suicidal germination induction and increase of inorganic $\mathrm{N}$ soil availability (Gacheru and Rao, 2005). In fact, Senna didymobotrya reduced striga emergence but did not increase maize yield due to low $\mathrm{N}$ content in foliar biomass; the opposite effect was observed with Tithonia diversifolia. Senna occidentalis, Cajanus cajan and natural fallow affected neither striga control nor maize productivity. However, on a highly infested field, C. grahamiana, Crotalaria spectabilis and S. sesban were unable to reduce striga infection.

Under dry rainfed conditions of Nigeria, alternating sorghum and bambara groundnut plants within the same row reduced striga shoots by 56-91\%, whereas alternate row intercropping reduced it by 45-96\% compared to sole sorghum (Gworgwor, 2002).

In western Kenya, Oswald et al. (2002) showed that the intercropping planting scheme (ridge vs flat or in-row vs alternating rows) did not influence maize grain yield, but ridge planting improved intercrop yield and reduced striga density. The best companion plants for maize were peanut, bean, yellow gram (a chickpea type), bambara nut and soybean, increasing farm productivity by 40-120\%. Yellow gram showed the higher and more stable striga control across years and locations. Shading, higher humidity and lower temperatures under the intercrop canopy were likely the mechanisms responsible for striga suppression. Coupling intercropping with hand weeding of mature striga plants would impede replenishment of the weed soil seedbank. However, less consistent effects of intercropping and of relay cropping of sorghum with legume shrubs (e.g., Sesbania sesban) on striga control were observed in the dry Tigray region of northern Ethiopia (Reda et al., 2005a, b). In the same region, Wubeneh and Sanders (2006) advocated development of intermediate and longer season striga-resistant cultivars to increase productivity in moderate and good rainfall years instead of overemphasizing short cycled varieties to deal with both drought and witchweed. This would increase farmers' adoption rate of potential innovations.

Improved striga control in agroforestry systems has been observed in western Kenya (Kiwia et al., 2009), especially using coppicing fallow legume species (Gliricidia sepium, Leucaena trichandra and Calliandra calothyrsus) because of up to eight-fold higher biomass production than non-coppicing legume species (Sesbania sesban, Mucuna pruriens, and Tephrosia vogelii). The amount of leafy biomass incorporated into the soil was positively correlated with striga reduction $(r=0.87)$. However, in the same region, Sjögren et al. (2010) 
found that continuous maize cultivation with good direct weed control may provide more effective $S$. hermonthica control than fallowing with sesbania, regardless of fallow duration.

Recent findings showed that integrating Faidherbia albida (a legume tree) into an Ethiopian sorghum field reduced striga infestation and improved mycorrhiza spore density and colonization (Birhane et al., 2018).

\subsubsection{Soil amendment, plant residues and mulching}

Besides allelopathic effects, intercropping cereals with legumes or introducing legumes in crop rotations is expected to increase soil fertility and hence create less favorable soil conditions for striga establishment and growth (Schulz et al., 2003). Similarly, soil application of fertilizers or amendments is expected to reduce striga problems (Sauerborn et al., 2003). Overall, increasing soil fertility is considered a key component of any IWM strategy against striga (Ekeleme et al., 2014), although very recently this assertion has been challenged (Rodenburg and Bastiaans, 2018). Higher striga infestation in low fertility soils may depend on higher strigolactones production by roots of nutrient stressed crops, as shown on maize (Jamil et al., 2012b), sorghum (Jamil et al., 2013) and pearl millet (Jamil et al., 2014). In Nigeria, Adagba et al. (2002) showed that FARO 48 and FARO 11, two upland rice varieties normally susceptible to $S$. hermonthica, exhibited resistance and tolerance, respectively, when $\mathrm{N}$ fertilizer $\left(30-120 \mathrm{~kg} \mathrm{~N} \mathrm{ha}^{-1}\right)$ was applied, whereas three other cultivars still showed susceptibility. These results suggest that susceptible rice varieties may require higher $\mathrm{N}$ rates than resistant ones to reduce striga interference.

Recent large-scale on-farm studies conducted in western Africa provided sound evidence on soil parameters that are expected to favor or disfavor striga. Ekeleme et al. (2014) showed that S. hermonthica infestation severity in maize was positively correlated with soil $\mathrm{pH}$ and content of sand and silt, and negatively correlated with total $\mathrm{N}$, exchangeable $\mathrm{K}$ and $\mathrm{Ca}$. Kamara et al. (2014) showed that $S$. hermonthica infestation severity in sorghum and millet was positively correlated with soil $\mathrm{pH}$ and negatively with available $\mathrm{P}, \mathrm{Cu}$ (in sorghum), $\mathrm{Zn}$ (in millet) and exchangeable $\mathrm{K}$ (in sorghum). S. gesnerioides infestation severity in cowpea was positively correlated with $\mathrm{pH}$ and negatively with total $\mathrm{N}$, organic $\mathrm{C}$, exchangeable $\mathrm{Ca}$, cation exchange capacity, available $\mathrm{Mn}$ and $\mathrm{Cu}$.

Reduction of $S$. hermonthica by organic residues depend on their decomposition and $\mathrm{N}$ mineralization rates, mainly affected by $\mathrm{C}: \mathrm{N}$ ratio and lignin + polyphenols: $\mathrm{N}$ ratio. In western Kenya, residues with higher tissue 
$\mathrm{N}$ concentration and lower lignin and polyphenols concentration, and thus more rapid $\mathrm{N}$ mineralization (e.g., Tithonia diversifolia) had a higher effect on striga suppression, similar to that of $\mathrm{N}$ fertilizer application. Sesbania sesban biomass also decomposed rapidly but its effect on striga reduction was limited (Gacheru and Rao, 2001). Residues of Lantana camara and Croton megalocarpus, despite having limited effect on striga, increased crop yield due to supply of $10-13 \mathrm{~kg} \mathrm{Pha}^{-1}$ season $^{-1}$. In the same region, white lupin (Lupinus albus) grown as a cover crop grown before maize or as a companion crop increased maize yields in fields highly infested with S. hermonthica, likely due to an allelopathic effect (Weisskopf et al., 2009).

Application of composted chicken manure, either alone or in combination with $\mathrm{N}$ fertilizer, reduced and delayed striga growth and early infestation in sorghum by $62 \%$. Application of $\mathrm{N}$ alone reduced striga infestation by 83\% (Hassan et al., 2010).

Soil incorporated organic amendments of different C:N ratios significantly reduced S. hermonthica seed survival (Ayongwa et al., 2011). Soil ethylene concentration between 2 and 3 ppm was high enough to stimulate striga seed germination, but did not depend upon quality of the applied organic matter. Nutrient release through decomposition of organic matter is thought to be the cause of striga seedbank losses through enhanced seed decay.

An unusual approach to striga control has been proposed by Andrianjaka et al. (2007), who applied Cubitermes (a termite genus) mound powder as amendment to $S$. hermonthica-infested soil. In the amended soil, sorghum growth and mycorrhizal (AMF) colonization of sorghum plants were significantly greater than in the control. AMF colonization was negatively correlated with striga emergence and enhanced sorghum growth. It was suggested that addition of Cubitermes mound powder reduces $S$. hermonthica infestation indirectly, through its effect on the indigenous soil microflora.

\subsubsection{Sowing and planting technique}

Transplanting under rainfed field conditions of Kenya significantly increased grain yield compared to direct seeding in maize but not in sorghum (Oswald et al., 2001). Improved maize productivity was largely due to lower striga attachment and density, which were especially noticeable when maize seedlings were older than 17 days at transplanting. Due to high labor requirement, maize transplanting is likely feasible only in small areas highly infested with striga and where a plant nursery can be established, but in these 
conditions crop grain yield can be more than doubled. Rainfed maize transplanting was shown to reduce striga emergence in both resistant and susceptible varieties (Oswald and Ransom, 2002), improving grain yields from $50 \%$ to $100 \%$ compared to direct seeding.

A combination of deep planting, use of transplants and shallow soil tillage was found to strongly delay and reduce $S$. hermonthica emergence and growth in both a sensitive and a tolerant sorghum cultivar (Van Ast et al., 2005). All three measures combined delayed first emergence of striga by 4 weeks and substantially reduced yield loss. Field testing of this technique in Mali reduced striga infestation by $85 \%$ but neither delayed witchweed emergence nor improved sorghum yield, possibly because of a high natural striga soil seedbank.

Several EWM solutions against $S$. hermonthica in sorghum or S. gesnerioides in cowpea were tried in low-fertility soils of southern Benin (Vissoh et al., 2008). Changing cowpea sowing dates did not prove to be feasible due to drought risk. Compared to direct sowing, sorghum transplanting raised crop yield two to threefold and greatly reduced striga infestation, but filling the field gaps by transplanting sorghum from plant hills did not work out. Cowpea and groundnut trap crops increased subsequent maize yield but had only a slight effect on $S$. hermonthica infestation.

In Ethiopia, combination of resistant variety, tied-ridge tillage and $\mathrm{N}$ fertilizer application to improve striga control in highly infested soils was tested (Tesso and Ejeta, 2011). This strategy increased sorghum grain yield by $121 \%$ compared to the opposite strategy (susceptible variety, flat bed planting and no $\mathrm{N}$ fertilization). Although striga emergence was 152\% higher in tie-ridged plots, vigor of the parasitic plants was unaffected.

In directly sown upland rice in Tanzania, delayed sowing time decreased $S$. asiatica infestation, possibly because part of seeds would return to a state of dormancy from which they are unable to germinate (Tippe et al., 2017a). However, the opposite effect was observed in lowland rice fields on Rhamphicarpa fistulosa, a facultative parasitic plant which is becoming a new threat for Sub-Saharan lowland rainfed rice systems (Rodenburg et al., 2015), likely because of the slow early development of this weed (Tippe et al., 2017b).

\subsubsection{Biological control}

Biological control of striga has shown promising results, either alone or combined with other EWM tactics. Combining a Fusarium oxysporum-based mycoherbicide with a resistant or tolerant sorghum cultivar reduced striga 
densities by $95 \%$ and increased crop growth and yield by $50 \%$ in the Sudano-Sahelian savannah of Nigeria (Marley et al., 2004a). Excellent striga control (65-84\% reduction) has been observed by using two granular mycoherbicides (Foxy 2 \& PSM 197) on both susceptible and resistant maize and sorghum, although effects on yield were limited (Schaub et al., 2006).

One important technical issue in fungi-based biocontrol is the retainment of mycoherbicide formulation efficacy in the long-term. In this respect, encapsulated propagules of Fusarium oxysporum (Foxy 2 or PSM 197) in "Pesta" granules during storage has been proposed (Elzein et al., 2004; Venne et al., 2009). Pesta granules chlamydospore-based inoculum retained higher viability (up to 100\%) across different inoculum concentrations and storage temperatures, whereas microconidial and mycelial preparations were not viable after 1-year storage at room temperature. Pesta formulation made by incorporating Foxy 2 in a matrix composed of durum wheat-flour, kaolin, and sucrose proved to be fully effective after 5 years of storage (Elzein et al., 2008). However, Pesta formulations of Fusarium nygamai and F. abuharaz have shown contrasting results (Zahran et al., 2008a, b).

A host range study under controlled environment conditions showed that only $S$. asiatica and S. hermonthica were susceptible to Foxy 2, which completely prevented shoot emergence and proved to be highly selective, thus it was proposed to classify it as F. oxysporum f. sp. strigae (Elzein and Kroschel, 2006). It has been proposed to use this fungus as seed coating treatment in sorghum, to minimize inoculum amount and formulation cost, and to place the biocontrol agent in the potential infection zone of the host plant (Elzein et al., 2006). The best results were given by seed coating with $40 \%$ arabic gum plus dried chlamydospores. However, Avedi et al. (2014) reported failure in using Foxy 2 as biocontrol agent against $S$. hermonthica in maize fields in western Kenya.

Fourteen Fusarium isolates indigenous to Burkina Faso were greenhousescreened for striga control in sorghum. Isolates grown on compost were more effective in reducing striga seed germination than those grown on chopped sorghum straw (Yonli et al., 2006).

Twelve promising sorghum lines characterized by good agronomic traits, resistance to striga and compatibility with Fusarium oxysporum have been identified and proposed as suitable candidates for EWM/IWM strategies against S. hermonthica (Rebeka et al., 2013). Combination between host resistance and biocontrol is thought to be a key EWM strategy for striga in the years to come (Mrema et al., 2017, 2018; Shayanowako et al., 2018). 
Selected bacteria have also proved effective as biocontrol agents against striga. Hassan et al. (2009a) screened 36 bacterial isolates and strains, and found that a Pseudomonas putida strain and nine bacterial isolates reduced striga incidence by $90-100 \%$ at peak emergence (12 weeks after sorghum sowing). Bacterial inoculation of sorghum seeds also proved effective in delaying and reducing striga emergence, especially when combined with $\mathrm{N}$ application (47-70\% reduction). Combination of Azospirillum brasilense + Azomonas spp. reduced striga germination by $18-34 \%$, whereas $P$. putida, Bacillus spp., Azotobacter sp., and Bradyrhizobium japonicum + Azotobacter sp. inhibited haustorial establishment by $12-50 \%$ (Hassan et al., 2009b). Bacterial treatments were effective regardless of sorghum cultivar susceptibility to striga, but it was suggested to combine them with the use of tolerant or resistant cultivars (Hassan et al., 2009c). More recently, new bioactive bacterial isolates belonging to the genera Bacillus, Streptomyces and Rhizobium have been found (Neondo et al., 2017).

An elegant paper by Musyoki et al. (2015) showed that, contrary to their expectations, soil application of Foxy 2 promoted total rhizosphere native prokaryotes and ammonia-oxidizing archaea (AOA) in a sandy soil, while abundance of ammonia-oxidizing bacteria was unaffected. The effect on AOA was fastened by incorporation in soil of Tithonia diversifolia residues. In a $S$. hermonthica-infested clayey soil cropped to maize, AOA abundance was promoted, suggested their ability to adapt to the presence of biotic stressors. The underlying mechanism for the promoting effect of Foxy 2 on AOA is still to be elucidated.

Contrary to many other key weeds of Sub-Saharan Africa, no paper reported any potential agroecosystem service associated with Striga spp., with the only exception of Kiendrebeogo et al. (2005), who found that $S$. hermonthica extracts can have antioxidant potential.

\section{Ecological weed management and agroecosystem} services

\subsection{Contribution of ecological weed management to ecological intensification in Sub-Saharan Africa}

Many approaches and methods pertaining to EWM have been developed and proved to be successful in Sub-Saharan Africa. As such, EWM has full potential to meet one of the most important goals of ecological (and sustainable) intensification, i.e., reduction in the use of external (especially chemical) inputs in agroecosystems. 
Remarkably, effective EWM solutions exist for many weed species perceived as "worst" in Sub-Saharan Africa. Examples of success stories in EWM are (i) the use of trap crops to stimulate suicidal seed germination in parasitic weeds (Orobanche spp., Phelipanche spp., Striga spp.); (ii) the continuous development and use of resistant or tolerant crop cultivars to minimize damage from parasitic weeds; (iii) the introduction of legume-based intercrops or fallows to improve weed management and soil fertility and then considerably reduce or eliminate the use of synthetic herbicides and fertilizers.

The concept of EWM is still in its infancy, as demonstrated by the fact that use of this term is still rare in the scientific literature. Refinement of the EWM concept and clarification of its role in the context of the well established (although at times misused) concept of Integrated Weed Management could be important to foster its adoption. The definition of EWM proposed here (Section 1.3) may facilitate this process.

The number of studies addressing EWM approaches and solutions targeted to Sub-Saharan Africa for some of the commonly recognized "world's worst weeds" (Holm et al., 1977) is surprisingly limited. This is the case of, e.g., Convolvulus arvensis (12 records), Cuscuta spp. (10), Cynodon dactylon (4), Cyperus spp. (25), and Imperata cylindrica (5). Some of these species are perennials, i.e., species for which use of systemic herbicides (mainly glyphosate) has long represented an efficient and relatively cheap method (Baylis, 2000). However, the worldwide increasing occurrence of glyphosate resistant weed biotypes (Heap and Duke, 2018), and the success of some EWM methods on other troublesome perennial weeds should encourage scientists to increase the number of studies on EWM for these "worst" species too.

\subsection{Biodiversity: A tool to foster ecological weed management}

There is ample potential to apply biodiversity-based approaches and tools to improve weed management in agroecosystems. However, this potential is not yet fully exploited because the concept itself is fuzzy. Talking about "biodiversity" in general does not help to understand how it can contribute to EWM. A much better concept would be that of "functional biodiversity," here defined as "that part of the total biodiversity composed of clusters of elements (at the gene, species or habitat level) providing the same (agro)ecosystem service, that is driven by within-cluster diversity" (Moonen and Bàrberi, 2008). Applied to EWM, this definition highlights the importance 
of selecting (cluster of) elements (e.g., cultivars, companion species, management/habitat types) possessing traits that confer them a better weed suppression ability (i.e., the target agroecosystem service).

It is important to note that, depending on the context, the weed suppression service can be provided by (i) traits possessed by one single element, e.g., a striga-resistant cultivar or the use of desmodium as companion crop to maize or sorghum (functional identity); (ii) the complementarity of traits between elements, e.g., the use of a striga-resistant maize or sorghum cultivar in an intercrop with desmodium; (iii) the diversity of traits within an element, e.g., the use of a NERICA rice cultivar with broad-spectrum resistance against several striga ecotypes (functional diversity) (see Costanzo and Bàrberi, 2014 for a more detailed description of these functional categories). A functional trait approach has recently been proposed as criterion for the selection of multiservice cover crop species in banana, including enhanced weed suppression (Damour et al., 2015).

Understanding and embracing the concept of functional (agro)biodiversity would help fully unravel its potential to improve weed management in agroecosystems and would consequently foster EWM.

\subsection{Ecological weed management and small scale farming}

A considerable number of studies carried out in Sub-Saharan Africa was conducted in the framework of small scale farming. Noticeably, quite a number of these studies have seen the direct involvement of farmers through on-farm research and/or collective participatory actions, although top-down approaches-mainly linked to provision of technical inputs like seeds of improved cultivars or fertilizers-are also present. The outcome of on-farm participatory studies are particularly valuable to capture the attitude of smallholders to EWM-related innovations and their priority options, and taking into account their perspective is of paramount importance (see, e.g., Tippe et al., 2017b).

Despite regional differences, in general small-scale farmers are sensitive to EWM methods and willing to try them in their fields where clear benefits are demonstrated. However, risk aversion is an issue that should always be taken into account in the definition of the operational context because it may invalidate technically feasible solutions. Although EWM methods may increase labor requirement, this does not seem to be an important deterrent for EWM adoption (Kamara et al., 2008). Interestingly, farmers tended to prefer multi-purpose solutions, i.e., those providing simultaneously more 
agroecosystem services. An example of this is the inclusion of silverleaf or greenleaf desmodium as intercrop with maize or sorghum, which provides excellent control of Striga hermonthica, control of stemborers, and forage for cattle (Khan et al., 2007). Tactics able to provide more agroecosystem services at once (multifunctional agrobiodiversity) should then be prioritized in EWM because they will have higher chances to become real innovations.

The goal of EWM is to use functional biodiversity to improve weed suppression and not to protect general on-field or on-farm biodiversity. As a matter of fact, only few studies incidentally addressed this point. Although it can be expected that cropping system diversification and agricultural inputs reduction may benefit biodiversity, this remains to be fully demonstrated. Unfortunately, so far there is little recognition of the importance and possibility of reconciling protection of biodiversity with use of biodiversity, both in agricultural science and practice (Bàrberi, 2015).

\subsection{Interactions with other agroecosystem services}

In several studies, besides enhanced weed suppression EWM approaches and methods simultaneously provided other agroecosystem services (e.g., enhanced soil fertility and crop production, biological pest control). Other studies, instead, highlighted the existence of trade-offs between improved weed management and other services (e.g., reduced crop yield, increased pest or pathogen attack). The vast majority of both situations refer to methods like cover cropping or intercropping, and is a quite normal outcome of functional agrobiodiversity studies, especially in complex agroecosystems (see, e.g., Moonen et al., 2006). Where acceptable compromises are not possible, between-service conflicts can only be resolved by prioritizing one service (the most important in that context) at the expense of the others.

Application of EWM methods is likely to result in more diverse weed communities that can support a more diverse herbivore community providing an effective biological pest control service. The most classical example of synergy between the weed suppression and the biological pest control services is the intercrop between maize and desmodium (D. uncinatum or $D$. intortum), which can concurrently abate populations of the maize stemborer and of Striga hermonthica (e.g., Khan et al., 2000). Another classical example of synergy is the inclusion of legumes in managed fallows, that can significantly suppress weeds while increasing soil nitrogen status and yield of the following cereal crop (e.g., Cheruiyot et al., 2003). 
Examples of trade-offs in which higher weed suppression reduced provision of other agroecosystem services are (i) reduced biological control with soil tillage, (ii) reduced crop yield with narrow row spacing or use of grass mulch, (iii) increased maize cob borer presence with mucuna or canavalia cover crops. It should be noted that the opposite effect has also been found, see, e.g., the case of Tithonia diversifolia living mulch, which was beneficial to soil fertility and crop yield but increased the risk of Striga hermonthica infestation (Thor Smestad et al., 2002).

\subsection{Weeds as providers of agroecosystem services}

Numerous studies highlighted opportunities of using "weeds" for various useful purposes. The vast majority of key weed species-with the noticeable exception of Striga spp.- - could be exploited in many ways, some of which are unusual and may open up interesting entrepreneurial opportunities for small-scale farmers in Sub-Saharan Africa.

It is known that some weeds may support organisms belonging to higher or lower trophic levels, e.g., natural enemies of crop pests delivering the biological control service (Norris and Kogan, 2000). In the context of Sub-Saharan Africa, the most important agroecosystem services that can be provided by weeds are: (i) increase in soil fertility; (ii) biological regulation of pests, diseases, nematodes, and other weeds; (iii) alternative produce for humans and animals.

As to soil fertility, one species emerges above all the others: Chromolaena odorata, that is not at all perceived as a weed in some areas of, e.g., West Africa, where it is valued as a very useful fallow plant that can considerably increase soil fertility even in a short time period and therefore boost crop productivity (e.g., Koutika and Rainey, 2010). As to biological regulations, aqueous extracts of many weeds have been discovered to negatively interefere with the establishment of important insect pests, crop diseases and parasitic nematodes, and some may also be used to control other weeds through allelopathic mechanisms (e.g., Amoabeng et al., 2014; Shaukat et al., 2002). As to novel produce, many weeds have shown to be used, e.g., a potential source of medicines, as feed for cattle, poultry or fish, as renewable biomass for on-farm use, and for bioremediation of polluted soils (e.g., Atagana, 2011; Lanyasunya et al., 2008; Lewu and Afolayan, 2009; Saikia et al., 2015).

In an EWM approach, it is important to distinguish between plant species that are real weeds from those that can be beneficial. This distinction can only be done in any given agroecosystem context and in a participatory 
manner, i.e., with the active involvement of local farmers and other relevant stakeholders (see, e.g., the distinction between "good" and "bad" weeds in the classical paper of Chacon and Gliessman, 1982).

\subsection{Perspectives}

A synthesis of the scientific evidence and of the perspectives of on-farm application of the different EWM methods in Sub-Saharan Africa is presented in Table 3. New agroecological knowledge, e.g., on soil-crop-weed interactions,

Table 3 Scientific evidence and perspectives of on-farm application of EWM methods in Sub-Saharan Africa (scale: nil/limited/moderate/good/very good/excellent).

\section{Method Evidence Perspectives Notes}

\begin{tabular}{llll}
\hline Photocontrol & Limited & Nil & Not a priority in the region \\
\hline Mulching & Good & Very good & $\begin{array}{l}\text { Should be favored by adoption of } \\
\text { reduced and no-till systems }\end{array}$
\end{tabular}

\begin{tabular}{|c|c|c|c|}
\hline Sowing pattern & Very good & Very good & So far not fully exploited \\
\hline Transplanting & Very good & Moderate & High cost may limit adoption \\
\hline Fertilization & Very good & Good & To be coupled with other methods \\
\hline Irrigation & Good & Moderate & $\begin{array}{l}\text { Increased water scarcity may limit } \\
\text { adoption }\end{array}$ \\
\hline $\begin{array}{l}\text { Competitive/ } \\
\text { resistant genotypes }\end{array}$ & Excellent & Excellent & $\begin{array}{l}\text { Useful genepool is expected to } \\
\text { expand }\end{array}$ \\
\hline Polycultures & Excellent & Excellent & $\begin{array}{l}\text { Should be fostered by increased } \\
\text { recognition and importance of } \\
\text { functional agrobiodiversity }\end{array}$ \\
\hline Seed predation & Moderate & Limited & $\begin{array}{l}\text { Highly dependent on site-specific } \\
\text { conditions, may be obtained as side } \\
\text { effect }\end{array}$ \\
\hline Seed decay & Limited & Moderate & $\begin{array}{l}\text { So far largely untapped, may be } \\
\text { obtained as side effect }\end{array}$ \\
\hline $\begin{array}{l}\text { Increased } \\
\text { germination }\end{array}$ & Very good & Very good & $\begin{array}{l}\text { Use of trap crops is expected to } \\
\text { increase }\end{array}$ \\
\hline $\begin{array}{l}\text { Preventing seed } \\
\text { shedding }\end{array}$ & Excellent & Good & Labor scarcity may limit adoption \\
\hline $\begin{array}{l}\text { Direct weed } \\
\text { control methods }\end{array}$ & Good & Very good & $\begin{array}{l}\text { Development of simple mechanical } \\
\text { tools may partially replace hand } \\
\text { weeding and hand hoeing }\end{array}$ \\
\hline
\end{tabular}


may lead to the expansion of this list in the near future. Indeed, EWM should be seen as a flexible approach merging the best information available from science and practice and turning it into locally feasible strategies.

Sub-Saharan Africa is expected to be one of the world regions most likely to suffer from the effects of climate change (Barrios et al., 2006). The consequences of climate change on weeds and weed management are still to be elucidated. Rodenburg et al. (2011) reviewed the expected effect of climate change on weed communities and weed management in Africa rice production systems. Higher temperatures and limited water availability is expected to favor $\mathrm{C}_{4}$ over $\mathrm{C}_{3}$ species like rice. In contrast, elevated $\mathrm{CO}_{2}$ levels will improve the competitiveness of rice as relative to $\mathrm{C}_{4}$ weeds, and tolerance of rice against parasitic weeds, although the latter may be favored by indirect effects of climate change like increased frequency of extreme events or soil degradation. Elevated $\mathrm{CO}_{2}$ levels should promote below-ground growth more than above-ground growth, especially in perennial $\left(\mathrm{C}_{3}\right)$ species, making mechanical weed control more difficult. Rainfed rice production systems would probably be more vulnerable than flooded systems, whereas in irrigated, non-flooded systems, weeds are expected to become more troublesome, especially perennial rhizomatous $\mathrm{C}_{3}$ species and species adapted to hydromorphic conditions.

Undoubtedly, climate change will challenge existing crop production systems, yet EWM-due to the diversity of solutions-seems the best approach to face future weed problems in sub-Saharan Africa in a sustainable manner.

Issues like lack of farmers' motivation, insecure land tenure status, limited capability and facilities of extension staff, poor communication among scientists and, in general, among stakeholders have been recognized as serious obstacles against adoption of EWM in Africa. In East Africa, Kristjanson et al. (2012) observed the existence of a knowledge lock-in that hinders the pathway to innovations, especially where innovation would be particularly needed.

Recently, a "mental models" approach has been proposed to facilitate knowledge exchange and collaboration between scientists and practitioners with the ultimate goal of fostering EWM (Zwickle et al., 2014, 2016). It would be interesting to adapt such an approach to socio-economic contexts of Sub-Saharan Africa.

Transdiciplinary collaboration and scientists' engagement in participatory research and action has been recognized as key to future weed science (Jordan et al., 2016) and will be of fundamental importance to speed up and broaden the adoption of ecological weed management approaches and methods. 


\section{Acknowledgments}

The author wants to thank the FAO AGP-Plant Production and Protection for having given him the opportunity to write the report upon which this article is partly based. Within this FAO Unit, special thanks go to Dr. Gualbert Gbèhounou for providing valuable comments.

\section{References}

Abate, M., Mekbib, F., Hussien, T., Bayu, W., Reda, F., 2014. Assessment of genetic diversity in sorghum (Sorghum bicolor (L.) Moench) for reactions to Striga hermonthica (Del.) Benth. Aust. J. Crop. Sci. 8, 1248-1256.

Abate, M., Hussien, T., Bayu, W., Reda, F., 2017a. Screening of Ethiopian sorghum (Sorghum bicolor) landraces for their performance under Striga hermonthica -infested conditions. Plant Breed. 136, 652-662.

Abate, M., Hussien, T., Bayu, W., Reda, F., 2017b. Diversity in root traits of sorghum genotypes in response to Striga hermonthica infestation. Weed Res. 57, 303-313.

Abdulai, M.S., Denwar, N.N., Haruna, M., 2006. Combating the menace of Striga hermonthica infestation: an integrated approach adopted in north-eastern Ghana. J. Agron. 5, 617-620.

Abunyewa, A.A., Padi, F.K., 2003. Changes in soil fertility and Striga hermonthica prevalence associated with legume and cereal cultivation in the Sudan savannah zone of Ghana. Land Degrad. Dev. 14, 335-343.

Adagba, M.A., Lagoke, S.T.O., Imolehin, E.D., 2002. Nitrogen effect on the incidence of Striga hermonthica (Del.) Benth in upland rice. Acta Agronomica Hung 50, 145-150.

Adetimirin, V.O., Kim, S.K., Aken'Ova, M.E., 2000. Expression of mature plant resistance to Striga hermonthica in maize. Euphytica 115, 149-158.

Amoabeng, B.W., Gurr, G.M., Gitau, C.W., Stevenson, P.C., 2014. Cost: benefit analysis of botanical insecticide use in cabbage: implications for smallholder farmers in developing countries. Crop Prot. 57, 71-76.

Anderson, R.L., 2009. Impact of preceding crop and cultural practices on rye growth in winter wheat. Weed Technol. 23, 564-568.

Andrew, I.K.S., Storkey, J., Sparkes, D.L., 2015. A review of the potential for competitive cereal cultivars as a tool in integrated weed management. Weed Res. 55, 239-248.

Andrianjaka, Z., Bally, R., Lepage, M., Thioulouse, J., Comte, G., Kisa, M., Duponnois, R., 2007. Biological control of Striga hermonthica by Cubitermes termite mound powder amendment in sorghum culture. Appl. Soil Ecol. 37, 175-183.

Anonymous, 2006. Controlling "witchweed" in Sub-Saharan Africa. In: AATF Annual Report 2005: Harnessing the Potential of Public/Private Partnerships. African Agricultural Technology Foundation, Nairobi, pp. 8-13.

Armengot, L., Berner, A., Blanco-Moreno, J.M., Mäder, P., Sans, F.X., 2015. Long term feasibility of reduced tillage in organic farming. Agron. Sustain. Dev. 35, 339-346.

Ascard, J., 1994. Soil cultivation in darkness reduced weed emergence. Acta Hortic. $372,167-177$.

Atagana, H.I., 2011. Bioremediation of co-contamination of crude oil and heavy metals in soil by phytoremediation using Chromolaena odorata (L) King \& H.E. Robinson. Water Air Soil Pollut. 215, 261-271.

Atera, E.A., Itoh, K., Azuma, T., Ishii, T., 2012. Response of NERICA rice to Striga hermonthica infections in western Kenya. Int. J. Agric. Biol. 14, 271-275.

Avedi, E.K., Ochieno, D.M.W., Ajanga, S., Wanyama, C., Wainwright, H., Elzein, A., Beed, F., 2014. Fusarium oxysporum f. sp. strigae strain Foxy 2 did not achieve biological 
control of Striga hermonthica parasitizing maize in Western Kenya. Biol. Control 77, 7-14.

Ayongwa, G.C., Stomph, T.J., Belder, P., Leffelaar, P.A., Kuyper, T.W., 2011. Organic matter and seed survival of Striga hermonthica-mechanisms for seed depletion in the soil. Crop Prot. 30, 1594-1600.

Badu-Apraku, B., Lum, A.F., 2007. Agronomic performance of Striga resistant earlymaturing maize varieties and inbred lines in the savannas of West and Central Africa. Crop. Sci. 47, 737-750.

Badu-Apraku, B., Menkir, A., Fakorede, M.A.B., Lum, A.F., Obeng-Antwi, K., 2006. Multivariate analyses of the genetic diversity of forty-seven Striga resistant tropical early maturing maize inbred lines. Maydica 51, 551-559.

Bagavathiannan, M.V., Davis, A.S., 2018. An ecological perspective on managing weeds during the great selection for herbicide resistance. Pest Manag. Sci. 74 (10), 2277-2286.

Bàrberi, P., 2002. Weed management in organic agriculture: are we addressing the right issues? Weed Res. 42, 176-193.

Bàrberi, P., 2013. Functional agrobiodiversity: the key to sustainability? In: Bhullar, G.S., Bhullar, N.K. (Eds.), Agricultural Sustainability: Progress and Prospects in Crop Research. Elsevier, Amsterdam, pp. 3-20.

Bàrberi, P., 2015. Functional biodiversity in organic systems: the way forward? Sustain. Agric. Res. 4, 26-31.

Barrios, S., Bertinelli, L., Strobl, E., 2006. Climatic change and rural-urban migration: the case of sub-Saharan Africa. J. Urban Econ. 60, 357-371.

Bastiaans, L., Paolini, R., Baumann, D.T., 2008. Focus on ecological weed management: what is hindering adoption? Weed Res. 48, 481-491.

Baylis, A.D., 2000. Why glyphosate is a global herbicide: strengths, weaknesses and prospects. Pest Manag. Sci. 56, 299-308.

Bertholdsson, N.-O., 2010. Breeding spring wheat for improved allelopathic potential. Weed Res. 50, 49-57.

Birhane, E., Gebremeskel, K., Taddesse, T., Hailemariam, M., Hadgu, K.M., Norgrove, L., Negussie, A., 2018. Integrating Faidherbia albida trees into a sorghum field reduces striga infestation and improves mycorrhiza spore density and colonization. Agr. Syst. 92, 643-653.

Botanga, C.J., Alabi, S.O., Echekwu, C.A., Lagoke, S.T.O., 2003. Genetics of suicidal germination of Striga hermonthica (Del.) Benth by cotton. Crop. Sci. 43, 483-488.

Boukar, O., Kong, L., Singh, B.B., Murdock, L., Ohm, H.-W., 2004. AFLP and AFLPderived SCAR markers associated with Striga gesnerioides resistance in cowpea. Crop. Sci. 44, 1259-1264.

Bozkurt, M.L., Muth, P., Parzies, H.K., Haussmann, B.I.G., 2015. Genetic diversity of East and West African Striga hermonthica populations and virulence effects on a contrasting set of sorghum cultivars. Weed Res. 55, 71-81.

Carsky, R.J., Berner, D.K., Oyewole, B.D., Dashiell, K., Schulz, S., 2000. Reduction of Striga hermonthica parasitism on maize using soybean rotation. Int. J. Pest Manage. 46, 115-120.

Carsky, R.J., Akakpo, C., Singh, B.B., Detongnon, J., 2003. Cowpea yield gain from resistance to Striga gesnerioides parasitism in southern Bénin. Exp. Agric. 39, 327-333.

Chacon, J.C., Gliessman, S.R., 1982. Use of the "non weed" concept in the traditional tropical agroecosystems in southeastern Mexico. Agroecosystems 8, 1-11.

Charnikhova, T.V., Gaus, K., Lumbroso, A., Sanders, M., Vincken, J.P., De Mesmaeker, A., Ruyter-Spira, C.P., Screpanti, C., Bouwmeester, H.J., 2017. Zealactones. Novel natural strigolactones from maize. Phytochemistry 137, 123-131.

Cheruiyot, E.K., Mumera, L.M., Nakhone, L.N., Mwonga, S.M., 2003. Effect of legumemanaged fallow on weeds and soil nitrogen in following maize (Zea mays L.) and wheat 
(Triticum aestivum L.) crops in the Rift Valley highlands of Kenya. Aust. J. Exp. Agric. 43, 597-604.

Cissoko, M., Boisnard, A., Rodenburg, J., Press, M.C., Scholes, J.D., 2011. New Rice for Africa (NERICA) cultivars exhibit different levels of post-attachment resistance against the parasitic weeds Striga hermonthica and Striga asiatica. New Phytol. 192, 952-963.

Cloutier, D.C., van der Weide, R.Y., Peruzzi, A., Leblanc, M.L., 2007. Mechanical weed management. In: Upadhyaya, M.K., Blackshaw, R.E. (Eds.), Non-Chemical Weed Management. Principles, Concepts and Technology. CAB International, Wallingford, pp. 111-134.

Costanzo, A., Bàrberi, P., 2014. Functional agrobiodiversity and agroecosystem services in sustainable wheat production. A review. Agron. Sustain. Dev. 34, 327-348.

Damour, G., Garnier, E., Navas, M.L., Dorel, M., Risède, J.-M., 2015. Using functional traits to assess the services provided by cover plants: a review of potentialities in banana cropping systems. Adv. Agron. 134, 81-133.

Davis, A.D., 2010. Cover-crop roller-crimper contributes to weed management in no-till soybean. Weed Sci. 58, 300-309.

Davis, A.D., Taylor, E.C., Haramoto, E.C., Renner, K.A., 2013. Annual postdispersal weed seed predation in contrasting field environments. Weed Sci. 61, 296-302.

Doré, T., Makowski, D., Malézieux, E., Munier-Jolain, N., Tchamitchian, M., Tittonell, P., 2011. Facing up to the paradigm of ecological intensification in agronomy: revisiting methods, concepts and knowledge. Eur. J. Agron. 34, 197-210.

Douthwaite, B., Schulz, S., Olanrewaju, A.S., Ellis-Jones, J., 2007. Impact pathway evaluation of an integrated Striga hermonthica control project in Northern Nigeria. Agr. Syst. 92, 201-222.

Ekeleme, F., Jibrin, J.M., Kamara, A.Y., Oluoch, M., Samndi, A.M., Fagge, A.A., 2014. Assessment of the relationship between soil properties, Striga hermonthica infestation and the on-farm yields of maize in the dry Savannas of Nigeria. Crop Prot. 66, 90-97.

Ellis-Jones, J., Schulz, S., Douthwaite, B., Hussaini, M.A., Oyewole, B.D., Olanrewaju, A.S., White, R., 2004. An assessment of integrated Striga hermonthica control and early adoption by farmers in northern Nigeria. Exp. Agric. 40, 353-368.

Elzein, A., Kroschel, J., 2006. Host range studies of Fusarium oxysporum Foxy 2: an evidence for a new forma specialis and its implications for Striga control. J. Plant Dis. Protect. 20 (Suppl), 875-887.

Elzein, A., Kroschel, J., Müller-Stöver, D., 2004. Effects of inoculum type and propagule concentration on shelf life of Pesta formulations containing Fusarium oxysporum Foxy 2, a potential mycoherbicide agent for Striga spp. Biol. Control 30, 203-211.

Elzein, A., Kroschel, J., Leth, V., 2006. Seed treatment technology: an attractive delivery system for controlling root parasitic weed Striga with mycoherbicide. Biocontrol Sci. Tech. 16, 3-26.

Elzein, A., Kroschel, J., Cadisch, G., 2008. Efficacy of Pesta granular formulation of Strigamycoherbicide Fusarium oxysporum f. sp. strigae Foxy 2 after 5-year of storage. J. Plant Dis. Protect. 115, 259-262.

Emeghebe, A.M., Ellis-Jones, J., Schulz, S., Chikoye, D., Douthwaite, B., Kureh, I., Tarawali, G., Hussaini, M.A., Kormawa, P., Sanni, A., 2004. Farmers' perception of the Striga problem and its control in northern Nigeria. Exp. Agric. 40, 215-232.

Enserink, M., Hines, P.J., Vignieri, S.N., Wigginton, N.S., Yeston, J.S., 2013. The pesticide paradox. Science 341, 728-729.

Estep, M.C., van Mourik, T.A., Muth, P., Guindo, D., Parzies, H.K., Koita, O.A., Weltzien, E., Bennetzen, J.L., 2011. Genetic diversity of a parasitic weed, Striga hermonthica, on sorghum and pearl millet in Mali. Trop. Plant Biol. 4, 91-98.

Fenner, M., Thompson, K., 2005. The Ecology of Seeds. Cambridge University Press, Cambridge. 
Gacheru, E., Rao, M.R., 2001. Managing Striga infestation on maize using organic and inorganic nutrient sources in Western Kenya. Int. J. Pest Manage. 47, 233-239.

Gacheru, E., Rao, M.R., 2005. The potential of planted shrub fallows to combat Striga infestation on maize. Int. J. Pest Manage. 51, 91-100.

Gallandt, E.R., 2006. How can we target the weed seedbank? Weed Sci. 54, 588-596.

Gbèhounou, G., 2011. Does Conservation Tillage Call for More Herbicides? Unpublished literature review.

Gbèhounou, G., 2013. Guidance on Weed Issues and Assessment of Noxious Weeds in a Context of Harmonized Legislation for Production of Certified Seeds. FAO, Plant Production and Protection Division, Rome.

Gbèhounou, G., Adango, E., 2003. Trap crops of Striga hermonthica: in vitro identification and effectiveness in situ. Crop Prot. 22, 395-404.

Gbèhounou, G., Bàrberi, P., 2016. Weed management. In: Mainstreaming Ecosystem Services and Biodiversity Into Agricultural Production and Management in East Africa. FAO Technical Guidance Document, Rome, pp. 29-45.

Gethi, J.G., Smith, M.E., Mitchell, S.E., Kresovich, S., 2005. Genetic diversity of Striga hermonthica and Striga asiatica populations in Kenya. Weed Res. 45, 64-73.

Gómez, R., Liebman, M., Munkvold, G., 2014. Weed seed decay in conventional and diversified cropping systems. Weed Res. 54, 13-25.

Gurney, A.L., Press, M.C., Scholes, J.D., 2002. Can wild relatives of sorghum provide new sources of resistance or tolerance against Striga species? Weed Res. 42, 317-324.

Gurney, A.L., Grimanelli, D., Kanampiu, F., Hoisington, D., Scholes, J.D., Press, M.C., 2003. Novel sources of resistance to Striga hermonthica in Tripsacum dactyloides, a wild relative of maize. New Phytol. 160, 557-568.

Gurney, A.L., Slate, J., Press, M.C., Scholes, J.D., 2006. A novel form of resistance in rice to the angiosperm parasite Striga hermonthica. New Phytol. 169, 199-208.

Gworgwor, N.A., 2002. The use of legume trap crops for control of Striga hermonthica (Del.) Benth. in sorghum (Sorghum bicolor L. Moench) in northern Nigeria. Mededelingen $67,421-430$.

Gworgwor, N.A., Weber, H.C., 2003. Arbuscular mycorrhizal fungi-parasite-host interaction for the control of Striga hermonthica (Del.) Benth. in sorghum [Sorghum bicolor (L.) Moench]. Mycorrhiza 13, 277-281.

Gworgwor, N.A., Hudu, A.I., Joshua, S.D., 2002. Seed treatment of sorghum varieties with brine $(\mathrm{NaCl})$ solution for control of Striga hermonthica in sorghum. Crop Prot. 21, 1015-1021.

Hassan, M.M., Abdel Gain, M.E., Babiker, A.G.T., 2009a. Potential of bacterial strains and nitrogen in reduction of Striga hermonthica (Del.) benth. infesting sorghum. Adv. Environ. Biol. 3, 1-9.

Hassan, M.M., Abdel Gani, M.E.S., Babiker, A.G.E.T., 2009b. Selection of soil borne bacteria for suppression of Striga hermonthica (Del.) Benth. Adv. Nat. Appl. Sci. 3, 27-34.

Hassan, M.M., Abdel Gani, M.E.S., Babiker, A.G.E.T., 2009c. Management of Striga hermonthica in sorghum using soil rhizosphere bacteria and host plant resistance. Int. J. Agric. Biol. 11, 367-373.

Hassan, M.M., Yagoub, S.O., Gabouch, N.A., 2010. Effect of different levels of organic manure on Striga hermonthica (Del.) Benth. and sorghum growth. Biosci. Res. 7, 32-38.

Heap, I., Duke, S.O., 2018. Overview of glyphosate-resistant weeds worldwide. Pest Manag. Sci. 74, 1040-1049.

Hess, D.E., Dodo, H., 2004. Potential for sesame to contribute to integrated control of Striga hermonthica in the West African Sahel. Crop Prot. 23, 515-522.

Holm, L.G., Plucknett, D.L., Pancho, J.V., Herberger, J.P., 1977. The World's Worst Weeds. Distribution and Biology. University Press of Hawaii, Honolulu. 
Hooper, A.M., Hassanali, A., Chamberlain, K., Khan, Z., Pickett, J.A., 2009. New genetic opportunities from legume intercrops for controlling Striga spp. parasitic weeds. Pest Manag. Sci. 65, 546-552.

Hooper, A.M., Tsanuo, M.K., Chamberlain, K., Tittcomb, K., Scholes, J., Hassanali, A., Khan, Z.R., Pickett, J.A., 2010. Isoschaftoside, a C-glycosylflavonoid from Desmodium uncinatum root exudate, is an allelochemical against the development of Striga. Phytochemistry 71, 904-908.

Hussien, T., Mishra, B.B., Gebrekidan, H., 2006. A new parasitic weed (Alectra vogelii) similar to Striga on groundnut in Ethiopia. Trop. Sci. 46, 139-140.

Jamil, M., Charnikhova, T., Houshyani, B., van Ast, A., Bouwmeester, H.J., 2012a. Genetic variation in strigolactone production and tillering in rice and its effect on Striga hermonthica infection. Planta 235, 473-484.

Jamil, M., Kanampiu, F.K., Karaya, H., Charnikhova, T., Bouwmeester, H.J., 2012b. Striga hermonthica parasitism in maize in response to $\mathrm{N}$ and $\mathrm{P}$ fertilizers. Field Crop Res $134,1-10$.

Jamil, M., Van Mourik, T.A., Charnikhova, T., Bouwmeester, H.J., 2013. Effect of diammonium phosphate application on strigolactone production and Striga hermonthica infection in three sorghum cultivars. Weed Res. 53, 121-130.

Jamil, M., Charnikhova, T., Jamil, T., Ali, Z., Mohamed, N.E.M.A., van Mourik, T., Bouwmeester, H.J., 2014. Influence of fertilizer microdosing on strigolactone production and Striga hermonthica parasitism in pearl millet. Int. J. Agric. Biol. 16, 935-940.

Jordan, N., Schut, M., Graham, S., Barney, J.N., Childs, D.Z., Christensen, S., Cousens, R.D., Davis, A.S., Eizenberg, H., Ervin, D.E., Fernandez-Quintanilla, C., Harrison, L.J., Harsch, M.A., Heijting, S., Liebman, M., Loddo, D., Mirsky, S.B., Riemens, M., Neve, P., Peltzer, D.A., Renton, M., Williams, M., Recasens, J., Sønderskov, M., 2016. Transdisciplinary weed research: new leverage on challenging weed problems? Weed Res. 56, 345-358.

Kamara, A.Y., Ellis-Jones, J., Amaza, P., Omoigui, L.O., Helsen, J., Dugje, I.Y., Kamai, N., Menkir, A., White, R.W., 2008. A participatory approach to increasing productivity of maize through Striga hermonthica control in northeast Nigeria. Exp. Agric. 44, 349-364.

Kamara, A.Y., Ewansiha, S.U., Menkir, A., Tofa, A.I., 2012. Agronomic response of drought-tolerant and striga-resistant maize cultivars to nitrogen fertilization in the nigerian guinea savannahs. Maydica 57, 114-120.

Kamara, A.Y., Ekeleme, F., Jibrin, J.M., Tarawali, G., Tofa, I., 2014. Assessment of level, extent and factors influencing Striga infestation of cereals and cowpea in a Sudan Savanna ecology of northern Nigeria. Agric. Ecosyst. Environ. 188, 111-121.

Karaya, H., Njoroge, K., Mugo, S., Ariga, E.S., Kanampiu, F., Nderitu, J.H., 2012. Determination of levels of Striga germination stimulants for maize gene bank accessions and elite inbred lines. Int. J. Plant Prod. 6, 209-224.

Khan, Z.R., Pickett, J.A., Van Den Berg, J., Wadhams, L.J., Woodcock, C.M., 2000. Exploiting chemical ecology and species diversity: stem borer and striga control for maize and sorghum in Africa. Pest Manag. Sci. 56, 957-962.

Khan, Z.R., Hassanali, A., Overholt, W., Khamis, T.M., Hooper, A.M., Pickett, J.A., Wadhams, L.J., Woodcock, C.M., 2002. Control of witchweed Striga hermonthica by intercropping with Desmodium spp., and the mechanism defined as allelopathic. J. Chem. Ecol. 28, 1871-1885.

Khan, Z.R., Midega, C.A.O., Hassanali, A., Pickett, J.A., Wadhams, L.J., Wanjoya, A., 2006a. Management of witchweed, Striga hermonthica, and stemborers in sorghum, Sorghum bicolor, through intercropping with greenleaf desmodium, Desmodium intortum. Int. J. Pest Manage. 52, 297-302.

Khan, Z.R., Pickett, J.A., Wadhams, L.J., Hassanali, A., Midega, C.A.O., 2006b. Combined control of Striga hermonthica and stemborers by maize-Desmodium spp. intercrops. Crop Prot. 25, 989-995. 
Khan, Z.R., Midega, C.A.O., Hassanali, A., Pickett, J.A., Wadhams, L.J., 2007. Assessment of different legumes for the control of Striga hermonthica in maize and sorghum. Crop. Sci. 47, 730-736.

Khan, Z.R., Midega, C.A.O., Wanyama, J.M., Amudavi, D.M., Hassanali, A., Pittchar, J., Pickett, J.A., 2009. Integration of edible beans (Phaseolus vulgaris L.) into the push-pull technology developed for stemborer and Striga control in maize-based cropping systems. Crop Prot. 28, 997-1006

Kiendrebeogo, M., Dijoux-Franca, M.G., Lamien, C.E., Meda, A., Wouessidjewe, D., Nacoulma, O.G., 2005. Acute toxicity and antioxydant property of Striga hermonthica (Del.) Benth (Scrophulariaceae). Afr. J. Biotechnol. 4, 919-922.

Kifuko-Koech, M., Pypers, P., Okalebo, J.R., Othieno, C.O., Khan, Z.R., Pickett, J.A., Kipkoech, A.K., Vanlauwe, B., 2012. The impact of Desmodium spp. and cutting regimes on the agronomic and economic performance of Desmodium-maize intercropping system in western Kenya. Field Crop Res 137, 97-107.

Kim, S.K., Adetimirin, V.O., Thé, C., Dossou, R., 2002. Yield losses in maize due to Striga hermonthica in West and Central Africa. Int. J. Pest Manage. 48, 211-217.

Kirigia, D., Runo, S., Alakonya, A., 2014. A virus-induced gene silencing (VIGS) system for functional genomics in the parasitic plant Striga hermonthica. Plant Methods 10, 16.

Kiruki, S., Onek, L.A., Limo, M., 2006. Azide-based mutagenesis suppresses Striga hermonthica seed germination and parasitism on maize varieties. Afr. J. Biotechnol. $5,866-870$.

Kiwia, A., Imo, M., Jama, B., Okalebo, J.R., 2009. Coppicing improved fallows are profitable for maize production in striga infested soils of western Kenya. Agr. Syst. 76, 455-465.

Kountche, B.A., Hash, C.T., Dodo, H., Laoualy, O., Sanogo, M.D., Timbeli, A., Vigouroux, Y., This, D., Nijkamp, R., Haussmann, B.I.G., 2013. Development of a pearl millet Striga-resistant genepool: response to five cycles of recurrent selection under Striga-infested field conditions in West Africa. Field Crop Res 154, 82-90.

Koutika, L.S., Rainey, H.J., 2010. Chromolaena odorata in different ecosystems: weed or fallow plant? Appl. Ecol. Environ. Res. 8, 131-142.

Kristjanson, P., Neufeldt, H., Gassner, A., Mango, J., Kyazze, F.B., Desta, S., Sayula, G., Thiede, B., Förch, W., Thornton, P.K., Coe, R., 2012. Are food insecure smallholder households making changes in their farming practices? Evidence from East Africa. Food Sec. 4, 381-397.

Kuchinda, N.C., Kureh, I., Tarfa, B.D., Shinggu, C., Omolehin, R., 2003. On-farm evaluation of improved maize varieties intercropped with some legumes in the control of Striga in the Northern Guinea savanna of Nigeria. Crop Prot. 22, 533-538.

Kulkarni, S.S., Dosdall, L.M., Spence, J.R., Willenborg, C.J., 2015. Depth of seed burial and gender influence weed seed predation by three species of ground beetle (Coleoptera: carabidae). Weed Sci. 63, 910-915.

Kulkarni, S.S., Dosdall, L.M., Spence, J.R., Willenborg, C.J., 2016. Brassicaceous weed seed predation by ground beetles (Coleoptera: carabidae). Weed Sci. 64, 294-302.

Kureh, I., Kamara, A.Y., Tarfa, B.D., 2006. Influence of cereal-legume rotation on Striga control and maize grain yield in farmers fields in the Northern Guinea savanna of Nigeria. J. Agric. Rural. Dev. Trop. 107, 41-54.

Landis, D.A., Menalled, F.D., Costamagna, A.C., Wilkinson, T.K., 2005. Manipulating plant resources to enhance beneficial arthropods in agricultural landscapes. Weed Sci. 53, 902-908.

Lanyasunya, T.P., Wang, H., Kariuki, S.T., Mukisira, E.A., Abdulrazak, S.A., Kibitok, N.K., Ondiek, J.O., 2008. The potential of Commelina benghalensis as a forage for ruminants. Anim. Feed Sci. Technol. 144, 185-195.

Légère, A., Stevenson, F.C., Benoit, D.L., 2011. The selective memory of weed seedbanks after 18 years of conservation tillage. Weed Sci. 59, 98-106. 
Lendzemo, V.W., Kuyper, T.W., 2001. Effects of arbuscular mycorrhizal fungi on damage by Striga hermonthica on two contrasting cultivars of sorghum, Sorghum bicolor. Agric. Ecosyst. Environ. 87, 29-35.

Lendzemo, V.W., Kuyper, T.W., Kropff, M.J., Van Ast, A., 2005. Field inoculation with arbuscular mycorrhizal fungi reduces Striga hermonthica performance on cereal crops and has the potential to contribute to integrated Striga management. Field Crop Res 91, 51-61.

Lendzemo, V.W., Kuyper, T.W., Matusova, R., Bouwmeester, H.J., Van Ast, A., 2007. Colonization by arbuscular mycorrhizal fungi of sorghum leads to reduced germination and subsequent attachment and emergence of Striga hermonthica. Plant Signal. Behav. $2,58-62$.

Lendzemo, V.W., Kuyper, T.W., Urban, A., Vegvari, G., Puschenreiter, M., Schickmann, S., Langer, I., Steinkellner, S., Vierheilig, H., 2009. The arbuscular mycorrhizal host status of plants can not be linked with the Striga seed-germination-activity of plant root exudates. J. Plant Dis. Protect. 116, 86-89.

Lewu, F.B., Afolayan, A.J., 2009. Ethnomedicine in South Africa: the role of weedy species. Afr. J. Biotechnol. 8, 929-934.

Liebman, M., Gallandt, E.R., 1997. Many little hammers: ecological management of cropweed interactions. In: Jackson, L.E. (Ed.), Ecology in Agriculture. Academic Press, San Diego, pp. 291-343.

Liebman, M., Mohler, C.L., Staver, C.P., 2001. Ecological Management of Agricultural Weeds. Cambridge University Press, Cambridge.

Ma, Y.Q., Cheng, J.M., Inanaga, S., Shui, J.F., 2004. Induction and inhibition of Striga hermonthica (Del.) Benth. Germination by extracts of traditional chinese medicinal herbs. Agron. J. 96, 1349-1356.

Ma, Y.Q., Shui, J., Inanaga, S., Cheng, J., 2005. Stimulatory effects of Houttuynia cordata Thunb. On seed germination of Striga hermonthica (Del.) Benth. Allelopath. J. $15,49-56$.

Marles, S.M., Warkentin, T.D., Holm, F.A., 2010. Field pea seed residue: a potential alternative weed control agent. Weed Sci. 58, 433-441.

Marley, P.S., Aba, D.A., Shebayan, J., Musa, R., Sanni, A., 2004a. Integrated management of Striga hermonthica in sorghum using a mycoherbicide and host plant resistance in the Nigerian Sudano-Sahelian savanna. Weed Res. 44, 157-162.

Marley, P.S., Shebayan, J.A.Y., Aba, D.A., Idem, N.U.A., 2004b. Possibilities for control of Striga hermonthica in Sorghum (Sorghum bicolor) using neem (Azadiractha indica) and parkia (Parkia biglobosa)-based products. Int. J. Pest Manage. 50, 291-296.

Mbuvi, D.A., Masiga, C.W., Kuria, E., Masanga, J., Wamalwa, M., Mohamed, A., Odeny, D.A., Hamza, N., Timko, M.P., Runo, S., 2017. Novel sources of witchweed (Striga) resistance from wild sorghum accessions. Front. Plant Sci. 8, 116.

Mengesha, W.A., Menkir, A., Unakchukwu, N., Meseka, S., Farinola, A., Girma, G., Gedil, M., 2017. Genetic diversity of tropical maize inbred lines combining resistance to Striga hermonthica with drought tolerance using SNP markers. Plant Breed. 136, 338-343.

Menkir, A., 2006. Assessment of reactions of diverse maize inbred lines to Striga hermonthica (Del.) Benth. Plant Breed. 125, 131-139.

Menkir, A., Makumbi, D., Franco, J., 2012. Assessment of reaction patterns of hybrids to Striga hermonthica (del.) benth. under artificial infestation in Kenya and Nigeria. Crop. Sci. 52, 2528-2537.

Midega, C.A.O., Khan, Z.R., Amudavi, D.M., Pittchar, J., Pickett, J.A., 2010. Integrated management of Striga hermonthica and cereal stemborers in finger millet (Eleusine coracana (L.) Gaertn.) through intercropping with Desmodium intortum. Int. J. Pest Manage. 56, 145-151.

Midega, C.A.O., Pittchar, J., Salifu, D., Pickett, J.A., Khan, Z.R., 2013. Effects of mulching, N-fertilization and intercropping with Desmodium uncinatum on Striga hermonthica infestation in maize. Crop Prot. 44, 44-49. 
Midega, C.A.O., Wasonga, C.J., Hooper, A.M., Pickett, J.A., Khan, Z.R., 2017. Droughttolerant Desmodium species effectively suppress parasitic striga weed and improve cereal grain yields in western Kenya. Crop Prot. 98, 94-101.

Moonen, A.C., Bàrberi, P., 2008. Functional biodiversity: an agroecosystem approach. Agric. Ecosyst. Environ. 127, 7-21.

Moonen, A.C., Castro Rodas, N., Bàrberi, P., Petacchi, R., 2006. Field margin structure and vegetation composition effects on beneficial insect diversity at farm scale: a case study on an organic farm near Pisa. In: Rossing, W.A.H., Eggenschwiler, L., Poehling, H.M. (Eds.), Landscape Management for Functional Biodiversity. In: vol. 29, pp. 77-80. IOBC wprs Bulletin.

Mrema, E., Shimelis, H., Laing, M., Bucheyeki, T., 2017. Screening of sorghum genotypes for resistance to Striga hermonthica and $S$. asiatica and compatibility with Fusarium oxysporum f.sp. strigae. Acta Agric. Scand. Sect. B Soil Plant Sci. 67, 395-404.

Mrema, E., Shimelis, H., Laing, M., Mwadzingeni, L., 2018. Genetic analysis of the maximum germination distance of Striga under Fusarium oxysporum f. sp. strigae biocontrol in sorghum. J. Integr. Agric. 17, 1585-1593.

Musyoki, M.K., Cadisch, G., Enowashu, E., Zimmermann, J., Muema, E., Beed, F., Rasche, F., 2015. Promoting effect of Fusarium oxysporum [f.sp. strigae] on abundance of nitrifying prokaryotes in a maize rhizosphere across soil types. Biol. Control $83,37-45$.

Mutinda, S.M., Masanga, J., Mutuku, J.M., Runo, S., Alakonya, A., 2018. KSTP 94, an open-pollinated maize variety has postattachment resistance to purple witchweed (Striga hermonthica). Weed Sci. 66, 525-529.

Neondo, J.O., Alakonya, A.E., Kasili, R.W., 2017. Screening for potential Striga hermonthica fungal and bacterial biocontrol agents from suppressive soils in Western Kenya. Biol. Control 62, 705-717.

Norris, R.F., Kogan, M., 2000. Interactions between weeds, arthropod pests, and their natural enemies in managed ecosystems. Weed Sci. 48, 94-158.

Odhiambo, J.A., Vanlauwe, B., Tabu, I.M., Kanampiu, F., Khan, Z., 2011. Effect of intercropping maize and soybeans on Striga hermonthica parasitism and yield of maize. Arch. Phytopathol. Plant Protect. 44, 158-167.

O’Donovan, J.T., Harker, K.N., Turkington, T.K., Clayton, G.W., 2013. Combining cultural practices with herbicides reduces wild oat (Avena fatua) seed in the soil seed bank and improves barley yield. Weed Sci. 61, 328-333.

Oerke, E.-C., 2006. Crop losses to pests. J. Agric. Sci. 144, 31-43.

Oswald, A., Ransom, J.K., 2001. Striga control and improved farm productivity using crop rotation. Crop Prot. 20, 113-120.

Oswald, A., Ransom, J.K., 2002. Response of maize varieties to transplanting in Strigainfested fields. Weed Sci. 50, 392-396.

Oswald, A., Ransom, J.K., Kroschel, J., Sauerborn, J., 2001. Transplanting maize and sorghum reduces Striga hermonthica damage. Weed Sci. 49, 346-353.

Oswald, A., Ransom, J.K., Kroschel, J., Sauerborn, J., 2002. Intercropping controls striga in maize based farming systems. Crop Prot. 21, 367-374.

Pageau, K., Simier, P., Le Bizec, B., Robins, R.J., Fer, A., 2003. Characterization of nitrogen relationships between Sorghum bicolor and the root-hemiparasitic angiosperm Striga hermonthica (Del.) Benth. Using K15NO3 as isotopic tracer. J. Exp. Bot. 54, 789-799.

Peigné, J., Ball, B.C., Roger-Estrade, J., David, C., 2007. Is conservation tillage suitable for organic farming? A review. Soil Use Manage. 23, 129-144.

Petersen, J., 2005. Competition between weeds and spring wheat for 15N-labelled nitrogen applied in pig slurry. Weed Res. 45, 103-113.

Picasso, V.D., Brummer, E.C., Liebman, M., Dixon, P.M., Wilsey, B.J., 2008. Crop species diversity aff ects productivity and weed suppression in perennial polycultures under two management strategies. Crop. Sci. 48, 331-342. 
Pretty, J.N., Toulmin, C., Williams, S., 2011. Sustainable intensification in African agriculture. Int. J. Agric. Sustain. 9, 5-24.

Rebeka, G., Shimelis, H., Laing, M.D., Tongoona, P., Mandefro, N., 2013. Evaluation of sorghum genotypes compatibility with Fusarium oxysporum under Striga infestation. Crop. Sci. 53, 385-393.

Reda, F., Verkleij, J.A.C., Ernst, W.H.O., 2005a. Intercropping for the improvement of sorghum yield, soil fertility and Striga control in the subsistence agriculture region of Tigray (northern Ethiopia). J. Agron. Crop Sci. 191, 10-19.

Reda, F., Verkleij, J.A.C., Ernst, W.H.O., 2005b. Relay cropping of sorghum and legume shrubs for crop yield improvement and Striga control in the subsistence agriculture region of Tigray (northern Ethiopia). J. Agron. Crop Sci. 191, 20-26.

Riemens, M.M., van der Weide, R.Y., Bleeker, P.O., Lotz, L.A.P., 2007. Effect of stale seedbed preparations and subsequent weed control in lettuce (cv. Iceboll) on weed densities. Weed Res. 47, 149-156.

Rodenburg, J., Bastiaans, L., 2018. In: Are Striga spp. and Low Soil Fertility, Two Sides of the Same Coin? Proceedings $18^{\text {th }}$ EWRS Symposium, Lubiana, 17-21 June, p. 176.

Rodenburg, J., Johnson, D.E., 2009. Chapter 4 weed management in rice-based cropping systems in Africa. Adv. Agron. 103, 149-218.

Rodenburg, J., Bastiaans, L., Weltzien, E., Hess, D.E., 2005. How can field selection for Striga resistance and tolerance in sorghum be improved? Field Crop Res 93, 34-50.

Rodenburg, J., Bastiaans, L., Kropff, M.J., Van Ast, A., 2006. Effects of host plant genotype and seedbank density on Striga reproduction. Weed Res. 46, 251-263.

Rodenburg, J., Bastiaans, L., Schapendonk, A.H.C.M., Van Der Putten, P.E.L., Van Ast, A., Dingemanse, N.J., Haussmann, B.I.G., 2008. $\mathrm{CO}_{2}$-assimilation and chlorophyll fluorescence as indirect selection criteria for host tolerance against Striga. Euphytica $160,75-87$

Rodenburg, J., Saito, K., Kakaï, R.G., Touré, A., Mariko, M., Kiepe, P., 2009. Weed competitiveness of the lowland rice varieties of NERICA in the southern Guinea Savanna. Field Crop Res 114, 411-418.

Rodenburg, J., Riches, C.R., Kayeke, J.M., 2010. Addressing current and future problems of parasitic weeds in rice. Crop Prot. 29, 210-221.

Rodenburg, J., Meinke, H., Johnson, D.E., 2011. Challenges for weed management in African rice systems in a changing climate. J. Agric. Sci. 149, 427-435.

Rodenburg, J., Morawetz, J.J., Bastiaans, L., 2015. Rhamphicarpa fistulosa, a widespread facultative hemi-parasitic weed, threatening rice production in Africa. Weed Res. 55, 118-131.

Rodenburg, J., Cissoko, M., Kayongo, N., Dieng, I., Bisikwa, J., Irakiza, R., Masoka, I., Midega, C.A.O., Scholes, J.D., 2017. Genetic variation and host-parasite specificity of Striga resistance and tolerance in rice: the need for predictive breeding. New Phytol. 214, 1267-1280.

Rugutt, J.K., Rugutt, K.J., Berner, D.K., 2001. Limonoids from nigerian Harrisonia abyssinica, and their stimulatory activity against Striga hermonthica seeds. J. Nat. Prod. 64, 1434-1438.

Saikia, P., Gupta, U.N., Barman, R.S., Kataki, R., Chutia, R.S., Baruah, B.P., 2015. Production and characterization of bio-oil produced from Ipomoea carnea bio-weed. Bioenergy Res. 8, 1212-1223.

Sangeetha, C., Baskar, P., 2015. Allelopathy in weed management: a critical review. Afr. J. Agric. Res. 10, 1004-1015.

Sauerborn, J., Kranz, B., Mercer-Quarshie, H., 2003. Organic amendments mitigate heterotrophic weed infestation in savannah agriculture. Appl. Soil Ecol. 23, 181-186.

Schaub, B., Marley, P., Elzein, A., Kroschel, J., 2006. Field evaluation of an integrated Striga hermontica management in Sub-Saharan Africa: synergy between Striga-mycoherbicides (biocontrol) and sorghum and maize resistant varieties. J. Plant Dis. Protect. 20 (Suppl), 691-699. 
Schulz, S., Hussaini, M.A., Kling, J.G., Berner, D.K., Ikie, F.O., 2003. Evaluation of integrated Striga hermonthica control technologies under farmer management. Exp. Agric. 39, 99-108.

Shaukat, S.S., Siddiqui, I.A., Khan, G.H., Zaki, M.J., 2002. Nematicidal and allelopathic potential of Argemone mexicana, a tropical weed: allelopathic and nematicidal potential of Argemone mexicana. Plant and Soil 245, 239-247.

Shaw, W.C., 1982. Integrated weed management systems technology for pest management. Weed Sci. 30 (Suppl. 1), 2-12.

Shayanowako, A.T., Laing, M., Shimelis, H., Mwadzingeni, L., 2018. Resistance breeding and biocontrol of Striga asiatica (L.) Kuntze in maize: a review. Acta Agric. Scand. Sect. B Soil Plant Sci. 68, 110-120.

Showemimo, F.A., Kimbeng, C.A., Alabi, S.O., 2002. Genotypic response of sorghum cultivars to nitrogen fertilization in the control of Striga hermonthica. Crop Prot. 21, 867-870.

Sjögren, H., Shepherd, K.D., Karlsson, A., 2010. Effects of improved fallow with Sesbania sesban on maize productivity and Striga hermonthica infestation in Western Kenya. J. For. Res. 21, 379-386.

Tesso, T.T., Ejeta, G., 2011. Integrating multiple control options enhances striga management and sorghum yield on heavily infested soils. Agron. J. 103, 1464-1471.

Thor Smestad, B., Tiessen, H., Buresh, R.J., 2002. Short fallows of Tithonia diversifolia and Crotalaria grahamiana for soil fertility improvement in western Kenya. Agr. Syst. 55, 181-194.

Tillett, N.D., Hague, T., Grundy, A.C., Dedousis, A.P., 2008. Mechanical within-row weed control for transplanted crops using computer vision. Biosyst. Eng. 99, 171-178.

Tippe, D.E., Rodenburg, J., van Ast, A., Anten, N.P.R., Dieng, I., Kayeke, J., Cissoko, M., Bastiaans, L., 2017a. Delayed or early sowing: timing as parasitic weed control strategy in rice is species and ecosystem dependent. Field Crop Res 214, 14-24.

Tippe, D.E., Rodenburg, J., Schut, M., van Ast, A., Kayeke, J., Bastiaans, L., $2017 b$. Farmers' knowledge, use and preferences of parasitic weed management strategies in rain-fed rice production systems. Crop Prot. 99, 93-107.

Toh, S., Holbrook-Smith, D., Stokes, M., Tsuchiya, Y., McCourt, P., 2014. Detection of parasitic plant suicide germination compounds using a high-throughput Arabidopsis HTL/KAI2 strigolactone perception system. Chem. Biol. 21, 988-998.

Traoré, H., Yonli, D., Diallo, D., Sérémé, P., 2011. Suicidal germination of Striga hermonthica (Del.) Benth. by cotton, cowpea and groundnut genotypes in Burkina Faso. Int. J. Agric. Res. 6, 49-57.

Udom, G.N., Babatunde, F.E., Tenebe, V.A., 2007. Suppression of witch-weed (Striga hermonthica) in sorghum: cowpea mixture as affected by cowpea varieties and planting patterns. Int. J. Agric. Res. 2, 268-274.

Unachukwu, N.N., Menkir, A., Rabbi, I.Y., Oluoch, M., Muranaka, S., Elzein, A., Odhiambo, G., Farombi, E.O., Gedil, M., 2017. Genetic diversity and population structure of Striga hermonthica populations from Kenya and Nigeria. Weed Res. 57, 293-302.

Van Ast, A., Bastiaans, L., Katile, S., 2005. Cultural control measures to diminish sorghum yield loss and parasite success under Striga hermonthica infestation. Crop Prot. 24, 1023-1034.

Van Mourik, T.A., Bianchi, F.J.J.A., Van Der Werf, W., Stomph, T.J., 2008. Long-term management of Striga hermonthica: strategy evaluation with a spatio-temporal population model. Weed Res. 48, 329-339.

Venne, J., Beed, F., Avocanh, A., Watson, A., 2009. Integrating Fusarium oxysporum f. sp. strigae into cereal cropping systems in Africa. Pest Manag. Sci. 65, 572-580.

Vissoh, P.V., Gbèhounou, G., Ahanchede, A., Roling, N.G., Kuyper, T.W., 2008. Evaluation of integrated crop management strategies employed to cope with Striga infestation in permanent land use systems in southern Benin. Int. J. Pest Manage. 54, 197-206. 
Watling, J.R., Press, M.C., 2000. Infection with the parasitic angiosperm Striga hermonthica influences the response of the $\mathrm{C}_{3}$ cereal Oryza sativa to elevated $\mathrm{CO}_{2}$. Glob. Chang. Biol. 6, 919-930.

Weisskopf, L., Akello, P., Milleret, R., Khan, Z.R., Schulthess, F., Gobat, J.M., Le Bayon, R.C., 2009. White lupin leads to increased maize yield through a soil fertilityindependent mechanism: a new candidate for fighting Striga hermonthica infestation? Plant and Soil 319, 101-114.

Welsh, A.B., Mohamed, K.I., 2011. Genetic diversity of Striga hermonthica populations in Ethiopia: evaluating the role of geography and host specificity in shaping population structure. Int. J. Plant Sci. 172, 773-782.

Westerman, P.R., Luijendijk, C.D., Wevers, J.D.A., Van der Werf, W., 2011. Weed seed predation in a phenologically late crop. Weed Res. 51, 157-164.

Williams II, M.M., Boydston, R.A., 2013. Crop seeding level: implications for weed management in sweet corn. Weed Sci. 61, 437-442.

Wilson, J.P., Hess, D.E., Hanna, W.W., 2000. Resistance to Striga hermonthica in wild accessions of the primary gene pool of Pennisetum glaucum. Phytopathology 90, 1169-1172.

Worthington, M.L., Reberg-Horton, S.C., Jordan, D., Murphy, J.P., 2013. A comparison of methods for evaluating the suppressive ability of winter wheat cultivars against Italian Ryegrass (Lolium perenne). Weed Sci. 61, 491-499.

Wubeneh, N.G., Sanders, J.H., 2006. Farm-level adoption of sorghum technologies in Tigray, Ethiopia. Agr. Syst. 91, 122-134.

Yallou, C.G., Menkir, A., Adetimirin, V.O., Kling, J.G., 2009. Combining ability of maize inbred lines containing genes from Zea diploperennis for resistance to Striga hermonthica (Del.) Benth. Plant Breed. 128, 143-148.

Yonli, D., Traoré, H., Hess, D.E., Sankara, P., Sérémé, P., 2006. Effect of growth medium, Striga seed burial distance and depth on efficacy of Fusarium isolates to control Striga hermonthica in Burkina Faso. Weed Res. 46, 73-81.

Yonli, D., Traoré, H., Sérémé, P., Sankara, P., 2010. Use of local plant aqueous extracts as potential bio-herbicides against Striga hermonthica (Del.) Benth. In Burkina Faso. Asian J. Crop Sci. 2, 147-154.

Zahran, E., Sauerborn, J., Abbasher, A.A., Ahmed, E.A., Mohukker, R.I., Karlovsky, P., Mohamed, E.A., Müller-Stöver, D., 2008a. "Pesta" and alginate delivery systems of Fusarium spp. for biological control of Striga hermonthica (Del.) Benth. under Sudanese field conditions. Biol. Control 44, 160-168.

Zahran, E., Sauerborn, J., Elmagid, A.A., Abbasher, A.A., Müller-Stöver, D., 2008b. Granular formulations and seed coating: delivery options for two fungal biological control agents of Striga hermonthica. J. Plant Dis. Protect. 115, 178-185.

Zwickle, S., Wilson, R., Doohan, D., 2014. Identifying the challenges of promoting ecological weed management (EWM) in organic agroecosystems through the lens of behavioral decision making. Agric. Hum. Values 31, 355-370.

Zwickle, S., Wilson, R., Bessette, D., Herms, C., Doohan, D., 2016. Facilitating ecological weed management decisions by assessing risk-benefit tradeoffs. Agroec. Sustain. Food Syst. 40, 635-659.

\section{Further reading}

Khan, Z.R., Pickett, J.A., 2001. Habitat management strategies for the control of cereal stemborers and striga in maize in Kenya. Int. J. Trop. Insect Sci. 21, 375-380.

Odhiambo, J.J.O., 2011. Potential use of green manure legume cover crops in smallholder maize production systems in Limpopo province, South Africa. Afr. J. Agric. Res. 6, 107-112. 